Roy, C. L. 2018. Nest and brood survival of Ring-necked Ducks in relation to anthropogenic development and wetland attributes. Avian

Conservation and Ecology 13(1):20. https://doi.org/10.5751/ACE-01212-130120

Copyright (C) 2018 by the author(s). Published here under license by the Resilience Alliance.

Research Paper

\title{
Nest and brood survival of Ring-necked Ducks in relation to anthropogenic development and wetland attributes
}

Charlotte L. Roy ${ }^{1,2}$

${ }^{1}$ Forest Wildlife Populations and Research Group, Minnesota Department of Natural Resources, ${ }^{2}$ Wetland Wildlife Populations and Research Group, Minnesota Department of Natural Resources

\begin{abstract}
The boreal and hemiboreal forests are facing increasing anthropogenic development in areas that have traditionally been remote and inaccessible. Although these forests are recognized as important to breeding waterfowl, breeding season vital rates and the influence of anthropogenic development on these rates remain largely unexplored. I estimated nest and brood survival of Ring-necked Ducks (Aythya collaris) in the hemiboreal forest of Minnesota. I located 115 nests on 43 wetlands, radio-tagged 65 nesting hens, and monitored 32 broods. I considered the influence of distance to and density of buildings and roads, and road-surface type, as well as wetland characteristics and other variables hypothesized to influence waterfowl vital rates. The best-supported nest survival models included covariates for distance from the nest to nearest road and road-surface type. Nest survival declined with increasing distance from roads and was higher for nests near paved roads, at least when the distance was $<400 \mathrm{~m}$. However, an interaction term in the topranked model suggested the effect of road type varied as a function of distance from nest. The model-averaged estimate of 35-day nest survival, based on the top two models was $0.278(\mathrm{SE}=0.048)$. Brood survival increased with brood age and open water area, and decreased with nesting habitat area and distance from open water to nearest road. Cumulative brood survival to 30 days was 0.263 (SE $=0.035$ ). These findings indicate that roads may influence both nest and brood survival. Furthermore, higher brood survival at wetlands with less nesting habitat area and more open water area may explain why hens move broods. Conservation managers should consider how habitat needs change throughout the breeding season to adequately address the needs of Ring-necked Ducks. Further study is needed to understand how anthropogenic development can be incorporated into conservation planning.
\end{abstract}

\section{Survie des nids et des couvées de Fuligules à collier en relation avec le développement d'origine anthropique et les caractéristiques des milieux humides}

RÉSUMÉ. Les forêts boréales et hémi-boréales subissent une augmentation du développement d'origine anthropique dans des régions qui étaient autrefois éloignées et inaccessibles. Bien qu'on sache que ces forêts sont importantes pour la nidification de la sauvagine, les paramètres vitaux en saison de nidification et l'influence du développement d'origine anthropique sur ce groupe d'oiseaux demeurent grandement inexplorés. Les taux de survie de nids et de couvées de Fuligules à collier (Aythya collaris) ont été estimés dans la forêt hémi-boréale du Minnesota. Cent-quinze nids situés dans 43 milieux humides ont été localisés, 56 femelles nicheuses ont été équipées d'émetteurs radios et 32 couvées ont été suivies. L'effet de la distance et de la densité des bâtiments et des routes ont été examinés, tout comme le type de revêtement des routes, de même que les caractéristiques des milieux humides et d'autres variables pouvant influer les taux de survie de la sauvagine. Les modèles de survie des nids les meilleurs incluaient les covariables de la distance entre le nid et la route la plus près et le type de revêtement. La survie des nids a diminué lorsque la distance avec les routes était plus grande; elle était plus élevée pour les nids près des routes pavées, à tout le moins quand la distance était $<400 \mathrm{~m}$. Toutefois, un terme d'interaction dans le meilleur modèle donnait à penser que l'effet du type de route variait en fonction de la distance du nid. L'estimation de la survie des nids à 35 jours selon la moyenne tirée des deux meilleurs modèles était de 0,278 (erreur-type $=0,048$ ). La survie des couvées a augmenté avec l'âge des couvées et la superficie d'eau libre, et a diminué avec la quantité d'habitat de nidification et la distance entre l'eau libre et la route la plus près. La survie cumulative des couvées à 30 jours était de 0,263 (erreur-type $=0,035$ ). Ces résultats indiquent que les routes ont peut-être un effet sur la survie des nids et des couvées. De plus, la survie plus élevées des couvées dans les milieux humides comportant moins de superficie d'habitat de nidification et plus d'eau libre pourrait expliquer pourquoi les femelles déplacent leur couvée. Les gestionnaires chargés de la conservation des Fuligules à collier devraient tenir compte de leurs besoins changeant en matière d'habitat durant la saison de nidification. D'autres recherches sont nécessaires si on veut comprendre comment incorporer le développement d'origine anthropique dans la planification de la conservation.

Key Words: anthropogenic development; Aythya collaris; boreal; brood survival; forest; nest survival; Ring-necked Duck; road 


\section{INTRODUCTION}

The boreal forest is expected to experience severe climate change impacts (Saporta et al. 1998, IPCC 2001) and anthropogenic influences such as logging, mining, oil and gas extraction, and associated infrastructure are increasing (Slattery et al. 2011). The combination of climate change and increasing development and fragmentation may interact and produce synergistic effects (Dale et al. 2001). Concerns emanating from these impending changes have resulted in increased interest in understanding and conserving boreal forest waterfowl (Drever et al. 2012, Holopainen et al. 2015). Numerous duck species breed in the boreal forest, which is the second most important area for breeding ducks in North America (U.S. Fish and Wildlife Service 2002, Slattery et al. 2011). Yet impacts of anthropogenic influences on waterfowl breeding in the boreal forest are largely unknown, in part because of historically low anthropogenic development in these remote locations (Slattery et al. 2011, Holopainen et al. 2015). In the hemiboreal forest, a southern transitional zone of the boreal forest (Brandt 2009), many of the predicted changes for the more northerly continuous boreal forest zone are already occurring (MNDNR 2006).

Roads and other infrastructure are known to impact wildlife populations (reviews in Fahrig and Rytwinski 2009, BenítezLópez et al. 2010) and wetland habitat quality. Paved roads have less infiltration, more run-off, more sedimentation, and road salt use in snow-impacted areas (Siegel 2007, Kroening and Ferrey 2013). These effects degrade wetland quality and have a negative impact on vegetation, invertebrate communities, and contaminant availability (Siegel 2007, Kroening and Ferrey 2013). Roads also affect wildlife communities through road noise (Reijnen et al. 1996, Parris and Schneider 2008, Francis et al. 2009, Leipus et al. 2010, Francis and Barber 2013), avoidance and behavior modification (Trombulak and Frissell 2000, Fahrig and Rytwinski 2009, Benítez-López et al. 2010), traffic mortalities (Trombulak and Frissell 2000, Jaeger et al. 2005, Fahrig and Rytwinski 2009), habitat loss and impacts on connectivity (Trombulak and Frissell 2000, Jaeger et al. 2005), and increased human access (Trombulak and Frissell 2000, Benítez- López et al. 2010). Generally, negative effects of roads on wildlife outnumber positive effects (Fahrig and Rytwinski 2009).

Studies of the effects of roads, traffic, and dwellings on waterfowl are still limited. Negative effects of traffic have been documented on breeding densities of Northern Shovelers (Anas clypeata), whereas no effects were detected for Mallards (Anas platyrhynchos), Tufted Ducks (Aythya fuligula; Reijnen et al. 1996), or wetland use by Lesser Scaup (Aythya affinis) broods (Fast et al. 2004). Hilli-Lukkarinen et al. (2011) examined the influence of adjacent human dwellings on waterfowl communities, but such studies are few and results vary considerably among waterfowl species. Several studies have examined the effect of human recreational use of wetlands on birds during migration (Korschgen et al. 1985, Havera et al. 1992, Knapton et al. 2000), but comparable studies during the breeding season are scarce. Even basic studies of nesting success and brood survival of many species of boreal ducks are limited, although scaup have received more attention in recent years (Koons and Rotella 2003, Walker at al. 2005, and others).

The Ring-necked Duck (Aythya collaris) breeds in marshes, lakes, and bogs of the boreal and hemiboreal forest regions (Brandt
2009, Roy et al. 2012). Studies of wetland use by waterfowl communities in Canada include Ring-necked Ducks (Townsend 1966, Toft et al. 1982, DesGranges and Darveau 1985, Rempel et al. 1997, Paszkowski and Tonn 2000, Lemelin et al. 2010), but estimates of breeding season vital rates for Ring-necked Ducks are few. Koons and Rotella (2003) examined nest success in the Parklands of Manitoba, but the landscape had a minimal forest component. In Minnesota, the last study of Ring-necked Duck nesting success in the forest was during 1978-1984 (Roy et al. 2012), although a more recent study during 1985-1987 was conducted in the forest-prairie transition (Maxson and Riggs 1996). Elsewhere, nesting vital rate estimates for Ring-necked Ducks are decades old (Mendall 1958, Murdy 1965, Sarvis 1972, McAuley and Longcore 1988, 1989) and preceded the development of statistical methods to compare factors influential to nest survival (Dinsmore et al. 2002, Dinsmore and Dinsmore 2007).

I examined factors important in Ring-necked Duck nest and brood survival in the hemiboreal forest of Minnesota, a southern transitional zone of the boreal forest (Brandt 2009). The forested region of Minnesota is predicted to experience dramatic contraction as a result of climate change (Iverson and Prasad 2001), with spruce-fir forests shifting north out of Minnesota entirely. These forests are also experiencing increasing development and recreational use in areas that previously had limited road access (MNDNR 2006). Such changes increase the urgency of obtaining reliable baseline information for future comparison and to inform conservation efforts, but may also provide an opportunity to learn about impacts in advance of changes in more northern boreal regions where prediction is tenuous outside of historical parameters. I considered variables associated with anthropogenic development including buildings, distance to roads, and road-surface type, as well as wetland attributes, and other variables thought to influence waterfowl vital rates from the literature. I developed predictions of how anthropogenic development, wetland, nest-, brood-, and timespecific variables could influence nest survival and brood survival based on the existing literature (Tables 1 and 2) to further understanding of a comparatively poorly studied duck of the North American boreal forest.

\section{METHODS}

The study was conducted in northcentral Minnesota, within a 42$\mathrm{km}$ radius of the small city of Bemidji. This landscape is characterized by mixed forests and wetlands, including shallow open water lakes, deep marshes, peatlands, and bogs. I identified lakes to search for Ring-necked Duck nests in the spring and summer of 2008-2012 using locations from a helicopter survey for Ring-necked Ducks conducted 2004-2010 (Zicus et al. 2008, Lawrence and Giudice 2013) and ground surveys conducted on 14 lakes in the Bemidji area beginning in 1969 (Zicus et al. 2004). The survey data were used to identify land cover attributes of wetlands that Ring-necked Ducks used (USGS Gap Analysis Program [GAP]: GAP types 12 [open water] and 13 [floating aquatic] surrounded by GAP types 10 [lowland deciduous shrub], 14 [sedge meadow], and 15 [broadleaf sedge and cattail], Zicus et al. 2008). I identified 103 lakes with similar land cover attributes to those used in the two surveys, but excluded lakes where I had been denied access by landowners. Each year, I added wetlands where I observed Ring-necked Ducks on the water during early 
Avian Conservation and Ecology 13(1): 20

Table 1. Variables included in models of Ring-necked Duck (Aythya collaris) nest survival, the direction (+/-) of the predicted effect, and the biological basis for the hypothesis.

\begin{tabular}{|c|c|c|}
\hline Variable & $+/-$ & Possible Mechanisms \\
\hline \multicolumn{3}{|l|}{ Time specific variables } \\
\hline Season trend & - & $\begin{array}{l}\text { Nest survival changes throughout the season, such that earlier nests are more successful because } \\
\text { more experienced hens nest before young hens (Klett and Johnson 1982, Hepp and Kennamer 1993, } \\
\text { Devries et al. 2008). }\end{array}$ \\
\hline Nest age & + & $\begin{array}{l}\text { Vulnerability of nests changes with nest age because of changes in hen attentiveness or predator } \\
\text { detection rates (Klett and Johnson 1982, Stephens et al. 2005, Grant and Shaffer 2012) }\end{array}$ \\
\hline Year & & Nest survival varied annually during this study. \\
\hline \multicolumn{3}{|l|}{ Nest location variables } \\
\hline $\begin{array}{l}\text { Nest distance to main water body } \\
(\mathrm{m})\end{array}$ & - & Nests closer to open water have better hen escape routes, allowing less detection by predators. \\
\hline $\begin{array}{l}\text { Nest distance to nearest water } \\
\text { (includes channels, } \mathrm{m} \text { ) }\end{array}$ & - & $\begin{array}{l}\text { Nests closer to water have better hen escape routes, allowing less detection by predators. Hens } \\
\text { commonly nested along channels that were more distant from the main water body. }\end{array}$ \\
\hline Water depth at nest $(\mathrm{cm})$ & + & Nests over water have better hen escape routes, allowing less detection by predators. \\
\hline \multicolumn{3}{|l|}{ Wetland variables } \\
\hline Nesting habitat area (ha) & + & $\begin{array}{l}\text { More nesting habitat provides a greater area for predators to search for nests that occur at low } \\
\text { densities (or encounter by chance). }\end{array}$ \\
\hline Open water area (ha) & - & $\begin{array}{l}\text { As open water area increases, wetlands can support larger aquatic-based predator communities } \\
\text { (mink [Neovison vison], river otter [Lontra canadensis], Bald Eagles [Haliaeetus leucocephalus]). }\end{array}$ \\
\hline Total wetland size (ha) & - & Smaller wetlands are preferred for nesting and this has a biological basis in nest survival. \\
\hline \multicolumn{3}{|l|}{ Anthropogenic development variables } \\
\hline Distance: nest to nearest road $(\mathrm{m})$ & & Effects decline with distance from the road. \\
\hline & - & $\begin{array}{l}\text { Roads have a negative effect on nest survival through attraction of predators and scavengers that } \\
\text { consume roadkill or garbage or use roads as travel corridors. Furthermore, the addition of } \\
\text { pollutants, heavy metals (Morgan et al. 1983, Trombulak and Frissell 2000), and alterations to } \\
\text { surface water routing (Forman and Alexander 1998, Trombulak and Frissell 2000) may impact local } \\
\text { invertebrate food availability for hens. }\end{array}$ \\
\hline & + & $\begin{array}{l}\text { Roads have a positive effect on nest survival through greater mortality of terrestrial predators } \\
\text { (Trombulak and Frissell 2000, Jaeger et al. 2005) or through road avoidance behavior (Randa and } \\
\text { Yunger 2006). Pescador and Peris (2007) reported that depredation of artificial nests was lower near } \\
\text { high traffic roads and increased with distance, whereas near low traffic roads, the opposite pattern } \\
\text { was observed, perhaps due to foraging on roadkills. }\end{array}$ \\
\hline \multirow[t]{2}{*}{$\begin{array}{l}\text { Distance: nest to nearest building } \\
(\mathrm{m})\end{array}$} & - & $\begin{array}{l}\text { Buildings have a negative effect on nest success through attraction of predators like raccoons } \\
\text { (Procyon lotor) and skunks (Mephitis mephitis) to areas impacted by humans, but effects decline with } \\
\text { distance (Randa and Yunger 2006). }\end{array}$ \\
\hline & + & $\begin{array}{l}\text { Buildings have a positive effect on nest success through avoidance of human activity by some } \\
\text { predators (Randa and Yunger 2006). }\end{array}$ \\
\hline Distance: road to wetland edge $(\mathrm{m})$ & $-1+$ & $\begin{array}{l}\text { The impact of roads on predators and wetlands declines with distance from the wetland edge } \\
\text { (Forman and Alexander 1998, Trombulak and Frissell 2000). }\end{array}$ \\
\hline Distance: road to open water $(\mathrm{m})$ & $-/+$ & $\begin{array}{l}\text { The impact of roads on predators and wetlands declines with distance from the open water (Forman } \\
\text { and Alexander 1998, Trombulak and Frissell 2000). }\end{array}$ \\
\hline \multirow[t]{2}{*}{ Road type (paved > gravel) } & + & $\begin{array}{l}\text { Paved roads reduce predation more than gravel roads because of higher traffic volume or speed, } \\
\text { greater human activity, and higher predator mortality or avoidance (Forman and Alexander 1998, } \\
\text { Trombulak and Frissell 2000). Pescador and Peris (2007) reported that depredation of artificial nests } \\
\text { was lower near high traffic roads, and higher near low traffic roads. Klett and Johnson (1982) } \\
\text { reported higher nest success in Mallards (Anas platyrhynchos) near an interstate highway, which they } \\
\text { attributed to traffic repelling predators, but Cowardin et al. (1985) reported low nest success in } \\
\text { Mallards near gravel road rights-of-way. }\end{array}$ \\
\hline & - & $\begin{array}{l}\text { Paved roads increase predation more than gravel roads because they attract scavengers to roadkill } \\
\text { and garbage and/or provide a travel corridor. Furthermore, paved roads are associated with more } \\
\text { pollution and heavy metal additions, nutrient subsidies, deicing salts (Amrhein et al. 1992), and } \\
\text { alteration of surface or subsurface water flow (Forman and Alexander 1998, Trombulak and Frissell } \\
\text { 2000), which could affect macroinvertebrate availability and plant succession (Wilcox 1986). }\end{array}$ \\
\hline \multirow{2}{*}{$\begin{array}{l}\text { Meters of road within } 1.6 \mathrm{~km} \text { of } \\
\text { nest }\end{array}$} & - & Greater road density will have a more negative impact on invertebrate food availability for hens. \\
\hline & + & $\begin{array}{l}\text { Greater road density will increase road mortality of predators. A road density of } 0.6 \mathrm{~km} / \mathrm{km}^{2} \text { is the } \\
\text { threshold for impacts on large predators (Forman et al. 1997, see review in Forman and Alexander } \\
\text { 1998). }\end{array}$ \\
\hline $\begin{array}{l}\text { No. buildings within } 1.6 \mathrm{~km} \text { of } \\
\text { wetland }\end{array}$ & - & $\begin{array}{l}\text { More buildings will have a negative effect on nest survival by altering the predator community to } \\
\text { favor raccoons and skunks, rather than foxes (Vulpes vulpes), which favor more intact forested } \\
\text { landscapes. }\end{array}$ \\
\hline \multicolumn{3}{|l|}{ Interactions } \\
\hline $\begin{array}{l}\text { Nest distance to nearest road*road } \\
\text { type }\end{array}$ & & Proximity to roads has more impact, but that effect varies with the type of road (paved > gravel). \\
\hline
\end{tabular}


Fig. 1. Wetlands in the study area (in gray) in northcentral Minnesota, with those searched for Ring-necked Duck (Aythya collaris) nests during 2008-2012 indicated as black dots and those where nests were found indicated with additional hatching.

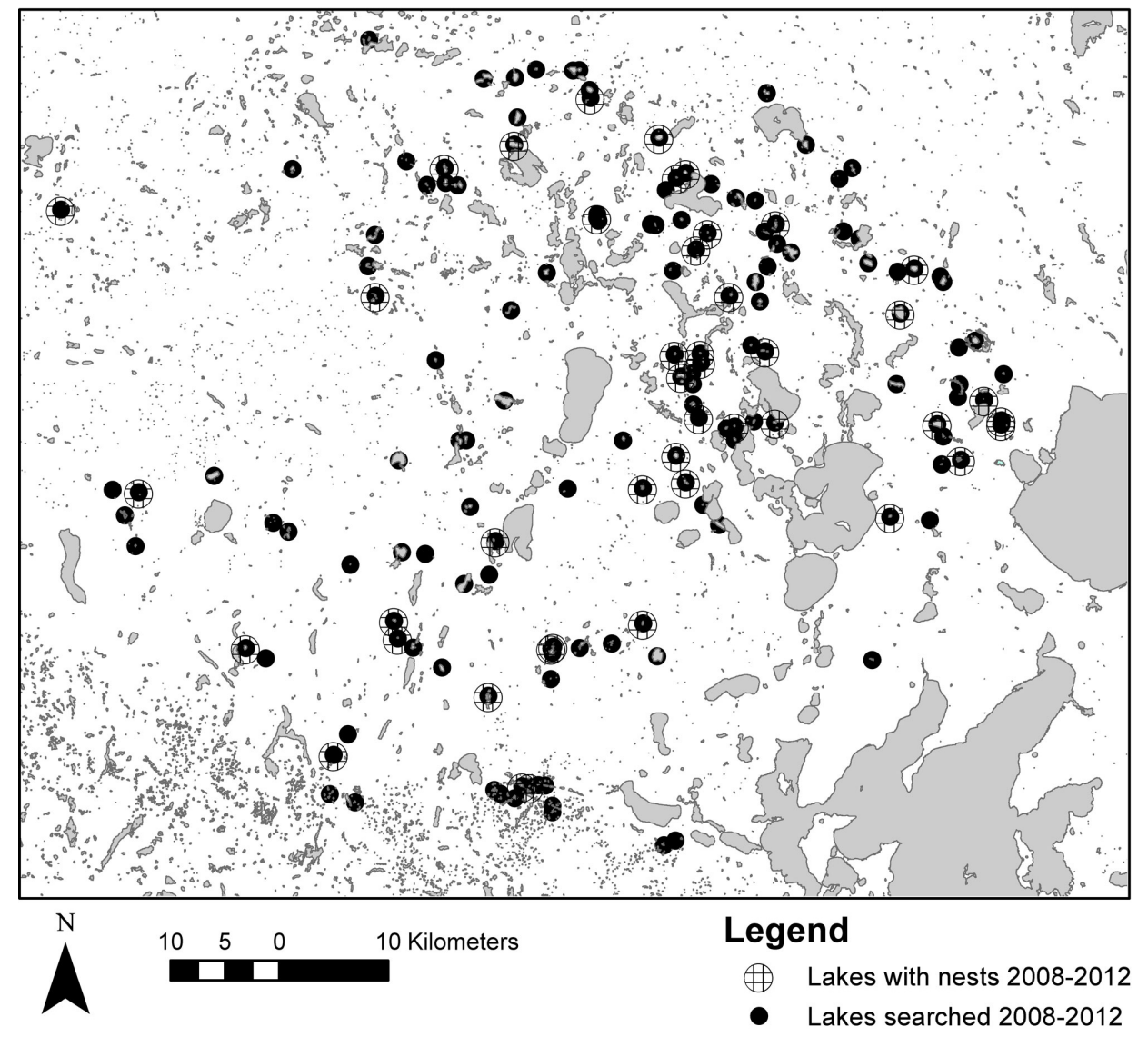

spring. I searched a total of 146 wetlands for Ring-necked Duck nests (Fig. 1) during 22 May-22 July 2008, 29 May-22 July 2009, 19 May-12 July 2010, 23 May-30 June 2011, 15 May-10 July 2012. Each wetland was searched up to four times per year, resulting in 497 searches.

I located nests by disturbing vegetation on floating bog mats and along wetland margins with bamboo poles and nest drags. I searched on foot with teams of two to six people, and from canoes when the bog mat was too unstable to support the weight of a person. When a nest was located, I determined the stage of incubation by candling eggs (Weller 1956) and recorded any new eggs in the nest in subsequent visits. I calculated nest initiation date from candling or hatching date. Nests were monitored every four to seven days to determine fate (abandoned, depredated, or successful). I determined water depth at nests and the distance between nests and open water, as well as the distance between nests and nearest water, i.e., including channels, at nest termination to minimize disturbance of bog vegetation around nests while the nest was active.

Late in incubation, I trapped hens on nests with Weller traps (Weller 1957) to attach radio-transmitters so that I could follow broods. During 2008-2009, I used a bib-type transmitter attachment method that had been used with previous success in Wood Ducks (Aix sponsa; Montgomery 1985, Granfors and Flake
1999) because I was concerned that a surgical transmitter attachment method might be too disruptive to incubating hens. The bib-type attachment method was faster and less invasive than surgical methods. Hens $(n=22)$ received a transmitter fastened to a Herculite fabric bib with dental floss and superglue (total weight of approximately $11 \mathrm{~g}$, and transmitting range of $\leq 2 \mathrm{~km}$ from the ground). I modified the method used unsuccessfully in Redheads (Aythya americana) by Sorenson (1989) by securing the bib more tightly and preening the bib into the breast feathers as in Montgomery (1985). After the transmitter was in place, I trimmed any excess fabric so that feathers concealed the transmitter and released the hen at the edge of the wetland. After the first 2 seasons, I discontinued using the bib-type transmitters because I was concerned about high harvest rates $(0.33)$ of hens with bib-type transmitters (C. Roy and J. Berdeen, personal communication), despite harvested hens appearing to have been in good condition at the time of harvest. Although survival during hunting season was not my focus, I was concerned about potential biases on nest and brood survival that I might not be able to detect without large sample sizes. During 2010-2012, I used the surgical transmitter attachment method of Korschgen et al. (1996a) to mark 43 hens in the field. I injected $0.6-0.8 \mathrm{ml}$ of the local anesthetic lidocaine ( $20 \mathrm{mg}$ per $\mathrm{ml}$ ) as used in Corcoran et al. (2007) before making $30 \mathrm{~mm}$ incision on the upper back, between the neck and scapula. I then made a subcutaneous pocket for the 
Table 2. Variables included in models of Ring-necked Duck (Aythya collaris) brood survival, the direction (+/-) of the predicted effect, and the biological basis for the hypothesis.

\begin{tabular}{|c|c|c|}
\hline Variable & $+/-$ & Possible Mechanisms \\
\hline \multicolumn{3}{|l|}{ Time specific variables } \\
\hline Date (linear) & - & $\begin{array}{l}\text { Early hatched broods have higher survival than late hatched broods (Ringelman } \\
\text { and Longcore 1982, Rotella and Ratti 1992, Dzus and Clark 1997). }\end{array}$ \\
\hline Year & & Brood survival varied annually during this study. \\
\hline \multicolumn{3}{|l|}{ Brood specific variables } \\
\hline Brood age $(\mathrm{d})$ & + & $\begin{array}{l}\text { Brood survival increases with brood age (McAuley and Longcore 1988, } \\
\text { Korschgen et al. 1996b). }\end{array}$ \\
\hline Brood size & + & $\begin{array}{l}\text { Larger broods will have higher brood survival (Pietz et al. 2003, Traylor and } \\
\text { Alisauskas 2006). }\end{array}$ \\
\hline Hen transmitter type & - & $\begin{array}{l}\text { Bib transmitter attachments will have greater impacts than implanted transmitters } \\
\text { because bibs have been unsuccessful in Redheads (Aythya americana; Sorensen } \\
\text { 1989). }\end{array}$ \\
\hline \multicolumn{3}{|l|}{ Wetland variables } \\
\hline Nesting habitat area (ha) & + & More nesting habitat buffers the impact of roads on wetlands. \\
\hline Open water area (ha) & + & $\begin{array}{l}\text { More open water area provides greater visibility of predators and enhanced brood } \\
\text { survival (note: few wetlands in our study had boat access or fish). }\end{array}$ \\
\hline Total wetland size (ha) & - & Comparatively larger wetlands have more predator use. \\
\hline \multicolumn{3}{|l|}{ Anthropogenic development variables } \\
\hline Distance: road to wetland edge $(\mathrm{m})$ & $+/-$ & $\begin{array}{l}\text { Road effects on wetland invertebrate communities and predator activity dissipate } \\
\text { with distance from the road to the wetland. }\end{array}$ \\
\hline Distance: road to open water $(\mathrm{m})$ & $+/-$ & $\begin{array}{l}\text { Road effects on wetland invertebrate communities and predator activity dissipate } \\
\text { with distance from the road to open water. }\end{array}$ \\
\hline \multirow[t]{2}{*}{ Road type } & + & $\begin{array}{l}\text { Paved roads reduce predation more than gravel roads because they are associated } \\
\text { with greater human activity and higher predator mortality or avoidance because } \\
\text { of higher traffic volume or speed (Forman and Alexander 1998, Trombulak and } \\
\text { Frissell 2000). }\end{array}$ \\
\hline & - & $\begin{array}{l}\text { Paved roads have a greater negative effect than gravel roads because of greater } \\
\text { human activity, more pollution and heavy metal additions, nutrient subsidies, } \\
\text { deicing salts (Amrhein et al. 1992), and alteration of surface or subsurface water } \\
\text { flow (Forman and Alexander 1998, Trombulak and Frissell 2000) that could affect } \\
\text { macroinvertebrate availability. These effects occur up to } 200 \mathrm{~m} \text { from roads and } \\
\text { increase with traffic volume (Trombulak and Frissell 2000). }\end{array}$ \\
\hline \multirow[t]{2}{*}{ Meters of road within $1.6 \mathrm{~km}$ of wetland } & + & $\begin{array}{l}\text { Greater road density will increase road mortality or avoidance behavior of some } \\
\text { predators (Philcox et al. 1999, Barthelmess and Brooks 2010). }\end{array}$ \\
\hline & - & $\begin{array}{l}\text { Greater road density will have a more negative impact on invertebrate food } \\
\text { availability for hens. }\end{array}$ \\
\hline $\begin{array}{l}\text { Number of buildings within } 1.6 \mathrm{~km} \text { of } \\
\text { wetland }\end{array}$ & + & $\begin{array}{l}\text { More buildings will have a positive effect on brood survival by deterring use by } \\
\text { Bald Eagles (Haliaeetus leucocephalus), mink (Neovison vison), and river otter } \\
\text { (Lontra canadensis; few wetlands had predatory fish in our study). }\end{array}$ \\
\hline \multicolumn{3}{|r|}{ 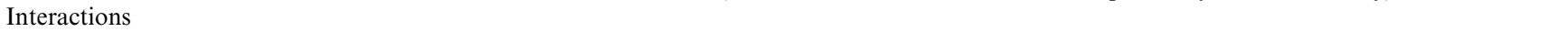 } \\
\hline Distance road to open water*road type & & $\begin{array}{l}\text { Brood survival changes with the distance of the open water portion of the wetland } \\
\text { from roads but effects are more pronounced for paved roads. }\end{array}$ \\
\hline Distance road to edge of wetland*road type & & $\begin{array}{l}\text { Brood survival changes with distance of the wetland edge from roads but effects } \\
\text { are more pronounced for paved roads. }\end{array}$ \\
\hline
\end{tabular}

transmitter with hemostats and created a small hole with a $2 \mathrm{~mm}$ stainless steel tube for the antenna to exit. I closed the incision with three to five sutures and applied a topical antibiotic to the incision and antenna exit site. Each bird was injected intramuscularly with penicillin to prevent infection. I also used $10 \mathrm{mg}$ per $\mathrm{kg}$ propofol postsurgery to reduce nest abandonment (Rotella and Ratti 1990, Machin and Caulkett 2000) after five hens abandoned following the first 13 surgeries. When propofol was used, hens were placed on nests rather than being released from the edge of the wetland so that they could recover from the propofol safely without disturbance. Harvest of hens with implanted transmitters was comparable to that of hens in an independently banded sample (0.05 vs 0.06) in 2010 (J. Berdeen, personal communication), and propofol alleviated abandonment, so I continued implanting transmitters in 2011 and 2012.
I monitored broods every three to seven days by homing to waterbodies with radio-tagged hens and observing broods until ducklings reached age Class III, i.e., 39-49 days (Gollop and Marshall 1954) or until total brood loss occurred. During 2009 and 2010, a fixed-wing aircraft outfitted with tracking antennas was used two to four times per season to locate hens that I could not find from the ground. I considered hens to have lost an entire brood if observed without ducklings more than once $(n=14)$ or if the hen could not be found after multiple attempts to find her on lakes near the last location $(n=7)$. I reasoned that if the hen was making large movements without affinity for any wetland, she had lost her brood (McAuley and Longcore 1988, Pietz et al. 2003). In three of these cases, I did not locate the hen again, which might have been due to longer movements away from the nesting location or possibly due to transmitter failure. 


\section{Data analysis}

I measured wetland area, open water area, and nesting habitat area (determined from aerial photographs as the sedge meadow, broadleaf sedge or cattail, and lowland scrub areas surrounding open water and floating emergents), and several anthropogenicdevelopment attributes in a Geographic Information System (GIS) using ArcMap 10.1 (Environmental Systems Research Institute, Inc., Redlands, California). To determine the proximity of nests, nesting habitat, and open water to roads, I measured the shortest distance from the edge of the nearest road in the Minnesota Department of Transportation GIS layer to the feature of interest using the U.S. Department of Agriculture Farm Service Agency (FSA) 2010 color aerial photography. I considered open water to be the main body of water, but not creeks, channels, or beaver drag areas. I determined wetland size (ha) as the area of open water plus the fringe of wetland vegetation, e.g., sedge and cattail. I determined open water area (ha) in ArcGIS as well, and calculated the area of nesting habitat as the difference between the total wetland area and open water area, i.e., emergent and wet meadow zones. I identified buildings within $1.6 \mathrm{~km}$ of the wetland with LIDAR and road-surface type from field notes taken during wetland visits.

I used the nest-survival module in Program MARK 8.0 (White and Burnham 1999, Rotella 2006, Cooch and White 2014) to estimate daily survival probabilities of nests as a function of covariates related to timing during the nesting season, nest- or hen-specific variables, wetland-level variables, and landscapelevel anthropogenic-development variables during the nest season (Tables 1 and 2). I included a seasonal trend variable to explain temporal variation in the nesting season, with earlier nests predicted to be more successful than later nests. I also included a model with nest age to allow nest survival to vary during laying and incubation (Klett and Johnson 1982, Stephens et al. 2005, Grant and Shaffer 2012). I included a model with annual variability, where year was modeled as a categorical variable. Nestlocation variables included water depth at the nest $(\mathrm{cm})$, distance to nearest water $(\mathrm{m})$, and shortest distance to open water $(\mathrm{m})$. Wetland characteristics included wetland size (ha), open water area (ha), and nesting habitat area (ha), which were transformed by dividing by a factor of 10 for better convergence. Anthropogenic-development variables included the number of buildings within $1.6 \mathrm{~km}$ of the wetland, meters of roads within $1.6 \mathrm{~km}$ of the wetland, the distance of the nest to the nearest road, the distance of the nest to the nearest building, and road-surface type (paved or gravel).

Other studies have reported seasonal variation in nest success in ducks (Klett and Johnson 1982, Hepp and Kennamer 1993, Emery et al. 2005, Devries et al. 2008), which may be related to age or condition of the nesting hen (Hohman 1986) or changes in predator behavior or nesting cover throughout the season. Such changes might also be influenced by nest and nest-site characteristics that influence predator encounter rates (Gerell 1970, Barding and Nelson 2008). I predicted wetland features would influence nest survival and predation risk because wetland features have been shown to be important indicators of Ringnecked Duck use (DesGranges and Darveau 1985, Rempel et al. 1997, Lemelin et al. 2010). I predicted that anthropogenic development would affect nest survival through impacts on wetland quality (Siegel 2007, Kroening and Ferrey 2013), the addition of pollutants and heavy metals (Morgan et al. 1983,
Trombulak and Frissell 2000), changes to surface and subsurface water routing, impacts on macroinvertebrate availability (McGurk and Fong 1995), disturbance associated with human activity (Trombulak and Frissell 2000, Benítez-López et al. 2010), and changes in predator mortality or avoidance behavior (Trombulak and Frissell 2000, Jaeger et al. 2005, Randa and Yunger 2006; Table 1). I expected road effects to be greater for paved roads because they have higher traffic volumes and travel speeds (Jahren et al. 2005). Unpaved roads in Minnesota generally have $\leq 100$ cars per day (Jahren et al. 2005) and probably substantially less in my study area. I did not include transmitter effects in models of nest survival because hens that received transmitters were more likely to be successful because of transmitter attachment late in incubation. Nests of hens that abandoned after transmitter implantation were censored.

I used the nest-survival module in Program MARK to estimate daily survival probabilities of broods and examine potential covariate effects. I examined covariates for temporal, broodspecific, wetland-specific, and landscape-level anthropogenicdevelopment variables (Table 2). I included models that allowed brood survival to vary over the season (with day 1 equal to the day the first nest hatched), and modeled season as both a linear trend and by year (Ringelman and Longcore 1982, Rotella and Ratti 1992, Guyn and Clark 1999, Traylor and Alisauskas 2006). Brood variables included brood age in days (d) and brood size at hatching (McAuley and Longcore 1988, Korschgen et al. 1996b, Traylor and Alisauskas 2006). Transmitter attachment type was also included in the brood survival model set. Wetland variables included open water area, nesting habitat area, and wetland size, as in the nest survival model set. When hens moved broods, I used attributes of the new lake (not the nest lake) in models of brood survival. A movement resulting in total brood loss between the nesting lake and the new brood-rearing lake would have been unlikely to be detected and attributes of the nesting lake were used in the models. Six hens moved Class I ducklings and two hens moved Class II ducklings. Anthropogenic development variables included surface type of the road nearest the wetland, distance between the road and open water, distance between the road and the wetland edge, the number of buildings within $1.6 \mathrm{~km}$ of the wetland, and total meters of roads within $1.6 \mathrm{~km}$ of the wetland. For cases in which the hen was observed repeatedly without her brood or could not be located after the nest hatched $(n=9)$, I assumed total brood loss at the IA stage (1-5 days). Thus my brood survival estimates may have been biased if creching occurred but was not detected on the few wetlands that had multiple broods of similar age (Roy et al. 2012). In 2011, the Minnesota government shut down for three weeks beginning 1 July and I was prohibited from tracking birds with broods $(n=$ 5) during that time. I did not include any 2011 broods in the analysis because of the long interval between locations and concern that inclusion could introduce bias in the survival estimate.

I used AICc (Akaike 1973, Sugiura 1978) to compare relative support for nest and brood survival models. I used a multistep approach to construct the model set in a stepwise fashion, first assessing temporal and nest-site-level factors, then using wetlandlevel and landscape-level anthropogenic-development variables. At each step, the best model was selected as the one with the smallest AICc value and then used in the next step. Models within two AICc units of the top-supported model (smallest AICc value) 
Table 3. Attributes (mean $\pm \mathrm{SD}$, and range) of wetlands searched for Ring-necked Duck (Aythya collaris) nests and those where nests were found or not found.

\begin{tabular}{|c|c|c|c|c|}
\hline Attribute & $\begin{array}{l}\text { Nesting wetlands } \\
\qquad(n=43)\end{array}$ & $\begin{array}{l}\text { Nesting wetlands near paved } \\
\text { roads } \\
(n=20)\end{array}$ & $\begin{array}{l}\text { Nesting wetlands near } \\
\text { gravel roads } \\
(n=23)\end{array}$ & $\begin{array}{l}\text { Wetlands without nests } \\
\qquad(n=103)\end{array}$ \\
\hline Wetland size (ha) & $\begin{array}{c}24.6 \pm 40.6 \\
(0.8-240)\end{array}$ & $\begin{array}{c}18.0 \pm 18.6 \\
(0.8-71)\end{array}$ & $\begin{array}{c}30.3 \pm 52.6 \\
(0.8-240)\end{array}$ & $\begin{array}{c}41.2 \pm 82.7 \\
(0.2-635)\end{array}$ \\
\hline Nesting habitat area (ha) & $\begin{array}{c}13.9 \pm 25.7 \\
(0.1-167)\end{array}$ & $\begin{array}{c}10.2 \pm 9.8 \\
(0.1-38)\end{array}$ & $\begin{array}{c}17.0 \pm 34.0 \\
(0.2-167)\end{array}$ & $\begin{array}{c}20.1 \pm 42.2 \\
(0.2-348)\end{array}$ \\
\hline Open water area (ha) & $\begin{array}{c}10.7 \pm 19.7 \\
(2.5-99)\end{array}$ & $\begin{array}{c}7.8 \pm 12.6 \\
(0.4-55)\end{array}$ & $\begin{array}{l}13.2 \pm 24.3 \\
(2.5-99)\end{array}$ & $\begin{array}{c}20.6 \pm 44.7 \\
(0.1-287)\end{array}$ \\
\hline Distance road to open water $(\mathrm{m})$ & $\begin{array}{c}114.2 \pm 182.0 \\
\left(0^{\dagger}-981\right)\end{array}$ & $\begin{array}{c}84.1 \pm 139.5 \\
\left(0^{\dagger}-579\right)\end{array}$ & $\begin{array}{c}148.2 \pm 215.2 \\
\left(0^{\dagger}-981\right)\end{array}$ & $\begin{array}{c}172 \pm 293 \\
(4-1470)\end{array}$ \\
\hline Distance nest to road (m) & $\begin{array}{c}218 \pm 160 \\
(1-914)\end{array}$ & $\begin{array}{c}233 \pm 145 \\
(20-710)\end{array}$ & $\begin{array}{c}205 \pm 176 \\
(1-914)\end{array}$ & NA \\
\hline Distance nest to building (m) & $\begin{array}{c}1301 \pm 1944 \\
(70-7878)\end{array}$ & $\begin{array}{l}438 \pm 423 \\
(70-2175)\end{array}$ & $\begin{array}{c}2276 \pm 2471 \\
(116-7878)\end{array}$ & NA \\
\hline Buildings within $1.6 \mathrm{~km}$ & $\begin{array}{l}43.6 \pm 40.8 \\
(0-126)\end{array}$ & $\begin{array}{l}60.8 \pm 34.8 \\
(0-126)\end{array}$ & $\begin{array}{l}24.2 \pm 38.6 \\
(0-125)\end{array}$ & NA \\
\hline Roads within 1.6 km (m) & $\begin{array}{c}8361 \pm 3371 \\
(3076-18,247)\end{array}$ & $\begin{array}{c}8527 \pm 2774 \\
(3076-14,866)\end{array}$ & $\begin{array}{c}8174 \pm 3958 \\
(3647-18,247)\end{array}$ & NA \\
\hline
\end{tabular}

${ }^{\dagger}$ Wetlands $0 \mathrm{~m}$ from roads were bisected by the road.

but differing by just one parameter and having similar maximized log-likelihood values were excluded from further consideration (sensu Burnham and Anderson 2002, Arnold 2010).

I used the delta method (Seber 1982) to compute standard errors (SE). Summary statistics are reported as mean \pm SE. I extracted beta estimates $(\hat{\beta})$ and variance-covariance matrices $(\Sigma)$ of my top models $(\triangle \mathrm{AICc}<2)$ from Program MARK, and used this information in the $\mathrm{R}$ programming language ( $\mathrm{R}$ Core Team 2017) to graphically evaluate the associations between covariates and predicted mean daily survival probabilities $(\hat{p})$ of nests and broods. I used the function 'deltamethod' in the R package 'msm' (Jackson 2011) to compute $\operatorname{Var}(\hat{p})$ based on the inverse logit transformation of $\mathrm{X} \hat{\beta}$, where $\mathrm{X}$ was a model matrix containing simulated, mean, or bootstrapped covariate values. For comparison with previous studies that reported nest or brood success (vs. daily survival probabilities), I computed cumulative survival probabilities $(\hat{\mathrm{S}})$ based on a $35-\mathrm{d}$ nest-survival interval $(9$ days for laying + 26 days for incubation) and a 30 -d brood-survival interval. I also used the R function 'deltamethod' (Jackson 2011) to compute $\operatorname{Var}(\hat{S})$ based on $\hat{p}$, a product-estimator function

$$
\hat{S}_{35}=\hat{p}^{35}
$$

for nest survival, and

$$
\hat{S}_{30}=\prod_{i=1}^{30} \hat{p}_{i}
$$

for brood survival, and the $\operatorname{Var}(\hat{p})$ or variance-covariance matrix for $\hat{p}_{i}$ computed from the first application of the delta method. I used mean distance of nests from roads $(232.6 \mathrm{~m}$ for gravel roads, $209.1 \mathrm{~m}$ for paved roads) to compare $\mathrm{E}\left(\mathrm{S}_{35}\right)$ by road type for the each nest-survival model with $\triangle \mathrm{AICc}<2$, and I also computed a model-averaged estimate of $\mathrm{E}\left(\hat{S}_{35}\right)$ using the functions 'aictabCustom' and 'modavgCustom' in the $\mathrm{R}$ package 'AICcmodavg' (Mazerolle 2017, R Core Team 2017). I performed a similar exercise for brood survival based on mean covariate values for nesting habitat area (mean $=0.29 \mathrm{ha})$, open water area $($ mean $=1.62 \mathrm{ha})$, and distance from open water to nearest road $($ mean $=107.4 \mathrm{~m})$. The above estimates were conditioned on mean covariate values, which was useful for describing covariate effects, e.g., while holding other covariates constant. However, conditioning $\hat{S}_{35}$ and $\hat{S}_{30}$ on mean covariate values may not necessarily describe the overall cumulative survival probability of nests and broods in the study area if covariates are not normally distributed around mean values. Therefore, I also used a bootstrap routine to estimate cumulative survival probabilities for the study area based on my top models $(\triangle \mathrm{AICc}<2)$ and the observed distribution of covariates values in my sample of nests and broods. I used the function 'mvrnorm' in the R package 'MASS'(Venables and Ripley 2002), with $(\hat{\beta})$ and $(\Sigma)$ from Program MARK, to simulate a vector of regression coefficients for each top model, and then bootstrapped (with replacement) a new model matrix from my sample of nests and broods. I used the bootstrapped beta vector and model matrix to compute cumulative survival probabilities for each nest and brood record and then computed an expected value by averaging over individual probabilities. I repeated this process $1000 \mathrm{x}$ for each top nest- and brood-survival model, and used the mean and variance of the bootstrap estimates to compute model-averaged estimates of $\hat{S}_{35}$ and $\hat{S}_{30}$ for nest and brood survival, respectively, at the study-area level.

\section{RESULTS}

\section{Nests}

I found 115 Ring-necked Duck nests on 43 wetlands ( $29 \%$ of wetlands searched) during 2008-2012 (annual range: 14-32 nests per year). Forty-five nests (39\%) successfully hatched $\geq 1$ duckling, 41 nests were destroyed by predators, 5 hens were killed before hatch, 17 nests were abandoned, 5 were flooded, and 2 nests had final fates that could not be determined from nest remains. Wetlands where nests were found $(n=43)$ were generally smaller than those where nests were not found $(n=103)$, and those near paved roads were closer to buildings and had more buildings within a $1.6 \mathrm{~km}$ buffer (Table 3 ). Wetlands with a successful nest 
Table 4. Comparisons of models of Ring-necked Duck (Aythya collaris) daily nest survival (S) during 2008-2012 in northcentral Minnesota using Program MARK (White and Burnham 1999). Constant values are indicated in models with a (.), $\triangle A I C c$ is the change in Akaike's criteria (Akaike 1973) adjusted for finite sample sizes, $K$ is the number of model parameters, $w_{i}$ is the model weight, Dev is the Deviance. Models moving forward from the previous step are italicized.

\begin{tabular}{|c|c|c|c|c|}
\hline Model & $\Delta \mathrm{AICc}^{\dagger}$ & $K$ & $w_{i}$ & Dev \\
\hline \multicolumn{5}{|l|}{ Step $1-\mathrm{S}()+$. Temporal variables } \\
\hline $\mathrm{S}()$. & 0.00 & 1 & 0.45 & 283.5 \\
\hline S(decreasing through season) & 1.10 & 2 & 0.26 & 282.6 \\
\hline $\mathrm{S}$ (nest age) & 1.70 & 2 & 0.19 & 283.2 \\
\hline $\mathrm{S}$ (year) & 3.24 & 5 & 0.09 & 278.7 \\
\hline \multicolumn{5}{|l|}{ Step $2-\mathrm{S}()+$. Nest location variables } \\
\hline$S()$. & 0.00 & 1 & 0.30 & 283.5 \\
\hline $\mathrm{S}$ (distance to main water) & 0.38 & 2 & 0.25 & 281.9 \\
\hline $\mathrm{S}$ (distance to nearest water) & 0.46 & 2 & 0.24 & 282.0 \\
\hline $\mathrm{S}$ (water depth at the nest) & 0.71 & 2 & 0.21 & 282.2 \\
\hline \multicolumn{5}{|l|}{ Step 3-S(.) + Wetland level variables } \\
\hline S(nesting habitat area + open water area) & 0.00 & 3 & 0.45 & 278.2 \\
\hline$S()$. & 1.28 & 1 & 0.24 & 283.5 \\
\hline $\mathrm{S}($ open water area) & 2.71 & 2 & 0.12 & 282.9 \\
\hline S(nesting habitat area) & 3.03 & 2 & 0.10 & 283.3 \\
\hline S(total wetland size) & 3.28 & 2 & 0.09 & 283.5 \\
\hline \multicolumn{5}{|c|}{ Step 4- S(nesting habitat area + open water area) + Landscape-level anthropogenic-development variables } \\
\hline $\mathrm{S}($ nest distance to nearest road $*$ nearest road type) & 0.00 & 4 & 0.30 & 269.2 \\
\hline $\mathrm{S}($ nest distance to nearest road + nearest road type) & 0.76 & 3 & 0.20 & 271.9 \\
\hline $\mathrm{S}($ nest distance to nearest road $*$ road type + nest distance to nearest building) & 1.62 & 5 & 0.13 & 268.8 \\
\hline $\mathrm{S}($ nest habitat area + open water area + nest distance to near road $*$ nearest road type) & 2.12 & 6 & 0.10 & 267.3 \\
\hline $\mathrm{S}$ (nest distance to nearest road + nest distance to nearest building) & 2.27 & 3 & 0.10 & 273.4 \\
\hline $\mathrm{S}$ (nest distance to nearest road) & 3.35 & 2 & 0.06 & 276.5 \\
\hline S(nesting habitat area + open water area + road type) & 4.68 & 4 & 0.03 & 273.9 \\
\hline S(nesting habitat area + open water area + nest distance to nearest road) & 4.83 & 4 & 0.03 & 274.0 \\
\hline $\mathrm{S}($ nearest road type) & 4.86 & 2 & 0.03 & 278.1 \\
\hline$S($ nesting habitat area + open water area) & 7.05 & 3 & 0.01 & 278.2 \\
\hline $\mathrm{S}$ (nest distance to building) & 8.01 & 2 & 0.01 & 281.2 \\
\hline S(number of buildings in $1.6 \mathrm{~km}$ buffer) & 9.03 & 2 & 0.00 & 282.2 \\
\hline $\mathrm{S}($ distance road to wetland) & 9.69 & 2 & 0.00 & 282.9 \\
\hline $\mathrm{S}$ (distance road to open water) & 9.87 & 2 & 0.00 & 283.1 \\
\hline $\mathrm{S}$ (meters of road in $1.6 \mathrm{~km}$ buffer) & 10.27 & 2 & 0.00 & 283.5 \\
\hline $\mathrm{S}$ (buildings in $1.6 \mathrm{~km}$ buffer + meters roads in $1.6 \mathrm{~km}$ buffer) & 11.03 & 3 & 0.00 & 282.2 \\
\hline
\end{tabular}

${ }^{\dagger}$ Lowest AICc 277.20

in at least one year $(n=22)$ had more nesting to open water area $(11.7 \pm 2.4$ ha vs $5.6 \pm 1.6$ ha; $2: 1)$ than wetlands where nests were unsuccessful ( $7.5 \pm 1.5$ ha vs $14.2 \pm 6.2$ ha, or $1: 2$, respectively). Hens nested up to $380 \mathrm{~m}$ (median $=10 \mathrm{~m}$, IQR $=0.3$ to $25.6 \mathrm{~m}$ ) from water.

Average clutch sizes during my study ranged from $7.8 \pm 0.3$ to 9.1 \pm 0.6 annually. Clutch sizes near gravel roads $(8.2 \pm 0.3)$ were similar to those near paved roads $(8.6 \pm 0.2)$. I did not observe renesting during my study, although it was not expected given the late timing of transmitter attachment in incubation and the propensity for renesting attempts to occur only when nest loss occurs during laying or early in incubation (Mendall 1958, Hunt and Anderson 1966). Average egg hatching success, defined as the proportion of the eggs laid in the nest that eventually hatched, ranged from $0.81 \pm 0.06$ to $0.88 \pm 0.07$ annually. Eggs did not hatch because of partial depredation, flooding, and infertility or incomplete development. Hatching success near gravel roads was $0.77 \pm 0.08$ and $0.89 \pm 0.03$ near paved roads.
One hundred thirteen nests contributed information to nest survival modeling (annual range: 14-32). The top-ranked model of nest survival included an interaction between distance from nest to nearest road and road-surface type (Table 4). Two additional models warranted consideration because they were within two AICc units of the top-ranked model, and both included covariates for distance from nest to nearest road and road-surface type (Table 4). The second-ranked model was similar to the top-ranked model but the effects were additive. The thirdranked model included the interaction between distance and road type, plus an additive effect for distance from nest to nearest building. However, the latter parameter was uninformative (sensu Arnold 2010). Therefore, I restricted my inferences to the top two models, which comprised $50 \%$ of the cumulative model weight. Both models suggested the mean daily survival rate (DSR) decreased with increasing distance from nest to nearest road (Figs. 2A, 2B). Furthermore, both models suggested the mean DSR was higher for nests near paved roads, at least for distances $<400 \mathrm{~m}$. The average distance of nests to paved roads was $209.1 \mathrm{~m}$ and the 
Fig. 2. Predicted mean daily survival rates of Ring-necked Duck (Aythya collaris) nests based on (A) the top-ranked model, which included an interaction between distance from nest to nearest road and road-surface type, and (B) the next-best model based on additive effects. Confidence intervals $(85 \%)$ are shown as gray and cross-hatched polygons. Hatch marks are included to indicate successful nests at the top and unsuccessful nests at the bottom of the figure.
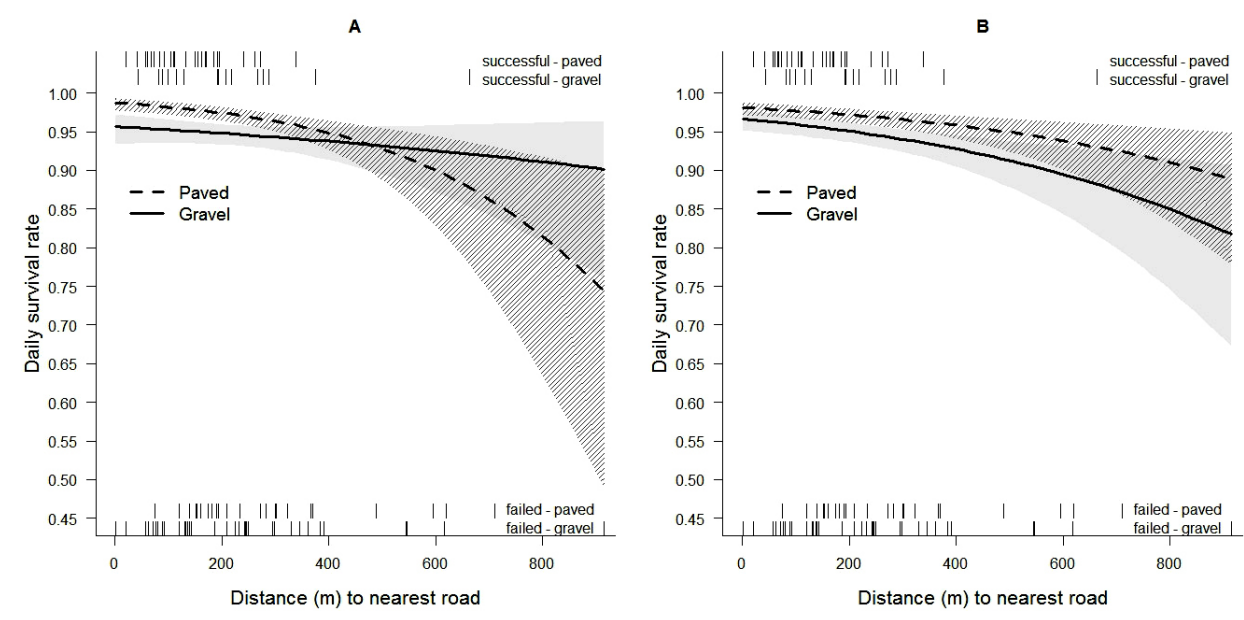

model-averaged estimate for 35-day survival at this distance was $0.377(\mathrm{SE}=0.080)$. Likewise, the model averaged estimate for 35 day nest survival at the mean distance to gravel roads $(232.6 \mathrm{~m})$ was $0.147(\mathrm{SE}=0.049)$. However, the top model suggested the effect of road type depended on distance from nest to road, and the mean DSR for nests near paved roads decreased more quickly than nests near gravel roads when distances were $>400 \mathrm{~m}$ (Fig. $2 \mathrm{~A})$. For the entire study area, the estimated cumulative survival probability for 35-days was $0.283(\mathrm{SE}=0.049)$ for the top-ranked model and $0.272(\mathrm{SE}=0.047)$ for the additive model. The modelaveraged estimate of 35-day survival for the study area, based on these two models only, was 0.278 ( $\mathrm{SE}=0.048)$.

\section{Broods}

I captured and radio-tagged 65 nesting hens and $49 \%$ of these hens contributed information on brood survival (annual range: $8-19)$. Of the 32 broods monitored, 8 hens successfully raised $\geq$ 1 duckling to age Class III (39-49 days), with 59\% losing entire broods during the first 10 days. The average size of successful broods was 4.4 ( $\mathrm{SE}=0.6)$ ducklings (range: $2-6)$. Average brood sizes for each age class (Gollop and Marshall 1954) were $6.4 \pm 0.6$ (IA, 1-5 days), $4.7 \pm 0.8$ (IB, 6-10 days), $5.1 \pm 0.8$ (IC, 11-16 days), $4.3 \pm 0.6$ (IIA, 17-24 days), $4.3 \pm 0.6$ (IIB, 25-30 days), $4.4+0.6$ (IIC, 31-38 days), and $4.3 \pm 0.7$ (III).

Eight broods (25\%) made an interwetland movement as Class I and II ducklings, and five crossed a road during these movements. Distances moved ranged 148-2273 m but seven of the eight movements were $\leq 860 \mathrm{~m}$ (measured from wetland edge). In seven movements, hens moved broods to wetlands with larger open water areas than nesting sites. Of the eight broods that moved, five later fledged, and three broods that did not fledge moved at the IA stage. Brood sizes observed immediately before and after movements did not change in three cases, but it was not uncommon for brood counts to differ by one or two ducklings in successive observations. All three of the broods that had similar brood sizes before and after movement, later fledged.

The most parsimonious model of brood survival included brood age, nesting habitat area, open water area, and distance from open water to nearest road (Table 5). One other model was within two AIC units of the top model but it only differed in how distance from the nearest road was defined, i.e., from the wetland edge, and the two distance metrics were strongly positively correlated ( $\rho=0.994)$. Therefore, I used the top-ranked model for inference. The mean DSR for broods increased with brood age and open water area, and decreased with nesting habitat area and distance from open water to nearest road (Fig. 3). The cumulative 30-day brood survival rate for the study area was $0.263(\mathrm{SE}=0.035)$.

\section{DISCUSSION}

Ring-necked Duck nest and brood survival were higher closer to roads; nest survival was inversely related to the distance of the nest from the nearest road, and a weaker pattern was detected for brood survival and distance of the road from open water. Roads can be beneficial to wildlife species whose predators are negatively impacted by them (Fahrig and Rytwynski 2009). Nest survival at wetlands near paved roads was also higher than at wetlands near gravel roads, at least for nests located within $400 \mathrm{~m}$ of roads. Such patterns might arise from stronger negative impacts of paved roads on nest and brood predators than for gravel roads (Fahrig and Rytwinski 2009, Wolff et al. 2015). Paved roads have higher traffic volumes and speeds, which would be expected to produce greater road mortality and/or avoidance by mammalian nest predators like raccoons (Procyon lotor) and striped skunks (Mephitis mephitis; Trombulak and Frissell 2000, Randa and Yunger 2006, Fahrig and Rytwinski 2009, Bartholomew and Brooks 2010, Wolff et al. 2015). Differences in traffic volume have been found to be important in studies of artificial nests (Pescador and Peris 2007). 
Table 5. Comparisons of models of Ring-necked Duck (Aythya collaris) brood survival (S) during 2008 -2012 (2011 excluded due to the Minnesota state government shutdown) in northcentral Minnesota using Program MARK (White and Burnham 1999). Constant values are indicated in models with a (.), $\triangle \mathrm{AICc}$ is the change in Akaike's criteria (Akaike 1973) adjusted for finite sample sizes, $K$ is the number of model parameters, $w_{i}$ is the model weight, Dev is the Deviance. Models moving forward from the previous step are italicized.

\begin{tabular}{|c|c|c|c|c|}
\hline Model & $\Delta \mathrm{AICc}^{\dagger}$ & $K$ & $w_{i}$ & Dev \\
\hline \multicolumn{5}{|l|}{ Step $1-\mathrm{S}()+$. Temporal variables } \\
\hline$S$ (brood age) & 0.00 & 2 & 0.49 & 139.0 \\
\hline $\mathrm{S}$ (brood age + date) & 0.35 & 3 & 0.41 & 137.3 \\
\hline $\mathrm{S}($ brood age + year + date $)$ & 5.41 & 6 & 0.03 & 136.3 \\
\hline $\mathrm{S}($ brood age + year $)$ & 5.90 & 5 & 0.03 & 138.8 \\
\hline $\mathrm{S}$ (date) & 6.09 & 2 & 0.02 & 145.1 \\
\hline $\mathrm{S}()$. & 6.95 & 1 & 0.02 & 147.9 \\
\hline S(year) & 12.43 & 4 & 0.00 & 147.4 \\
\hline \multicolumn{5}{|l|}{ Step 2 - S(brood age $)+$ Hen and brood specific variables } \\
\hline$S$ (brood age) & 0.00 & 2 & 0.50 & 139.0 \\
\hline S(brood age + initial brood size $)$ & 1.64 & 3 & 0.22 & 138.6 \\
\hline $\mathrm{S}$ (brood age + transmitter type $)$ & 1.93 & 3 & 0.19 & 138.9 \\
\hline S(brood age + initial brood size + transmitter type $)$ & 3.54 & 4 & 0.08 & 138.5 \\
\hline S(initial brood size) & 8.13 & 2 & 0.01 & 147.1 \\
\hline S(transmitter type) & 8.65 & 2 & 0.01 & 147.6 \\
\hline \multicolumn{5}{|l|}{ Step 3-S(brood age) + Wetland level variables } \\
\hline $\mathrm{S}$ (brood age + nesting habitat area + open water area) & 0.00 & 4 & 0.40 & 133.5 \\
\hline$S$ (brood age) & 1.45 & 2 & 0.20 & 139.0 \\
\hline $\mathrm{S}$ (brood age + nesting habitat area) & 2.24 & 3 & 0.13 & 137.7 \\
\hline S(brood age + wetland size $)$ & 2.45 & 3 & 0.12 & 138.0 \\
\hline $\mathrm{S}($ brood age + open water area $)$ & 3.23 & 3 & 0.08 & 138.7 \\
\hline S(nesting habitat area + open water area) & 3.79 & 3 & 0.06 & 139.3 \\
\hline S(nesting habitat area) & 8.06 & 2 & 0.01 & 145.6 \\
\hline $\mathrm{S}($ wetland size $)$ & 8.94 & 2 & 0.01 & 146.5 \\
\hline S(open water area) & 10.18 & 2 & 0.00 & 147.7 \\
\hline \multicolumn{5}{|l|}{$\begin{array}{l}\text { Step } 4 \text { - S(brood age + nesting habitat area }+ \text { open water area) + Landscape-level anthropogenic- } \\
\text { development variables }\end{array}$} \\
\hline $\begin{array}{l}\mathrm{S}(\text { brood age }+ \text { nesting habitat area }+ \text { open water area }+ \text { distance from nearest road to open water portion } \\
\text { of wetland) }\end{array}$ & 0.00 & 5 & 0.39 & 129.3 \\
\hline $\mathrm{S}($ brood age + nesting habitat area + open water area + distance from nearest road to wetland edge $)$ & 0.34 & 5 & 0.33 & 129.6 \\
\hline$S$ (brood age + nesting habitat area + open water area) & 2.16 & 4 & 0.13 & 133.5 \\
\hline $\mathrm{S}($ brood age + nesting habitat area + open water + roads in $1.6 \mathrm{~km}$ buffer $)$ & 2.70 & 5 & 0.10 & 132.0 \\
\hline $\mathrm{S}$ (brood age + nesting habitat area + open water + buildings in $1.6 \mathrm{~km}$ buffer) & 4.09 & 5 & 0.05 & 133.4 \\
\hline $\mathrm{S}$ (distance road to open water) & 10.51 & 2 & 0.00 & 145.9 \\
\hline $\mathrm{S}$ (distance road to edge of wetland) & 11.01 & 2 & 0.00 & 146.4 \\
\hline $\mathrm{S}$ (roads in a $1.6 \mathrm{~km}$ buffer) & 11.90 & 2 & 0.00 & 147.3 \\
\hline $\mathrm{S}$ (distance road to open water portion of wetland + road type) & 12.32 & 3 & 0.00 & 145.7 \\
\hline $\mathrm{S}$ (buildings in $1.6 \mathrm{~km}$ buffer) & 12.40 & 2 & 0.00 & 147.8 \\
\hline S(road type) & 12.40 & 2 & 0.00 & 147.8 \\
\hline S(distance road to edge of wetland + road type) & 12.87 & 3 & 0.00 & 146.2 \\
\hline S(distance road to open water portion of wetland * road type) & 13.30 & 4 & 0.00 & 144.6 \\
\hline S(distance road to edge of wetland $*$ road type $)$ & 13.91 & 4 & 0.00 & 145.2 \\
\hline
\end{tabular}

${ }^{\dagger}$ Lowest AICc 139.4

Relationships between roads and nest survival might be expected to be stronger than between roads and brood survival because the open water areas of wetlands are farther from roads than nesting habitats and the influence of roads dissipates with distance. Roads might also impact nest survival and brood survival differently if the predators most affected by roads are those more terrestrially based (raccoons, skunks, and foxes, Vulpes vulpes), than aquaticbased (mink, Neovison vison and river otter, Lontra canadensis), and terrestrial predators impact nest survival more than brood survival. In a New York study of road-killed mammals, raccoons
(15.5\%) and striped skunks (10.4\%) were among the most commonly found road-killed mammals (Barthelmess and Brooks 2010). By contrast, mink and red fox comprised a small proportion $(\leq 1 \%)$ of their sample. River otter and coyote (Canis latrans) were not detected, which they suggested was due to habitat specialization away from roads and behavioral avoidance of roads, respectively. Mink and otter would both be expected to concentrate activities near the open water portions of wetlands based on their behavior. Importantly, my study was observational and the exact cause of the relationships documented are uncertain. 
Fig. 3. Predicted mean daily survival rates of Ring-necked Duck (Aythya collaris) broods, based on the top-ranked additive model, as a function of (A) brood age, (B) nesting habitat area, (C) open water area, and (D) distance of open water from nearest road. Predictions are conditional on holding other predictors at mean values. Confidence intervals (85\%) are shown as gray polygons. Hatch marks are included to indicate successful broods at the top and unsuccessful broods at the bottom of the figure.
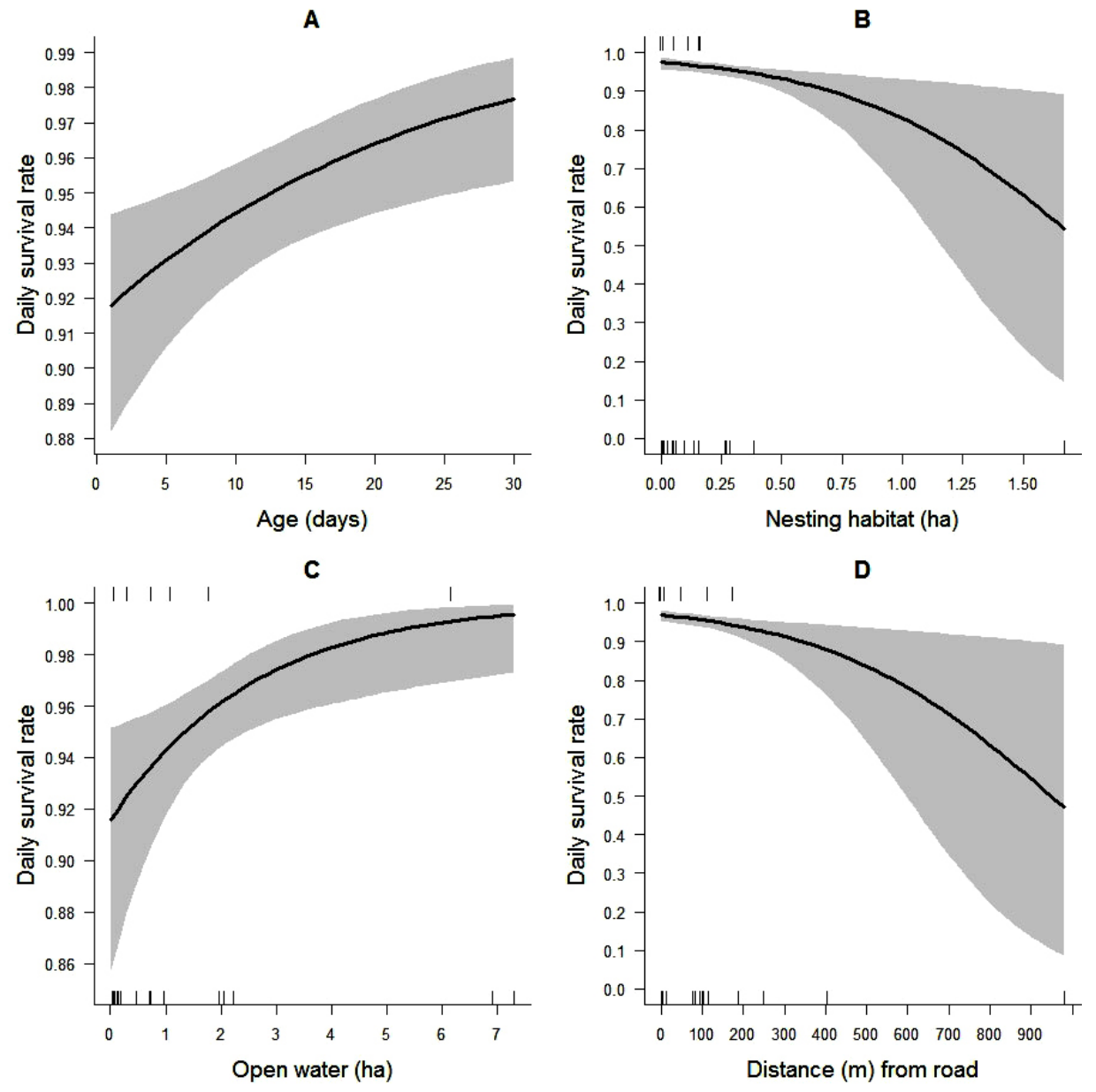

The distances between wetlands and roads in this study is comparable to other studies where roads have been reported to influence bird abundance (Benítez-López et al. 2010, Forman and Alexander 1998). However few of the nests I located were beyond $500 \mathrm{~m}$ from roads, which made it more difficult to reliably estimate effects farther away from roads and the different rate of decline for paved and gravel roads. A meta-analysis by Benítez-López et al. (2010) indicated that infrastructure, i.e., roads, can impact bird abundance at distances as far as $1 \mathrm{~km}$ and for mammals as far as $5 \mathrm{~km}$, although forested areas were affected over shorter distances than open areas. Interestingly, chemical impacts of roads on wetlands, e.g., addition of salt, nutrients, dust, and heavy metals, typically occur at distances $\leq 50 \mathrm{~m}$ (Forman and Alexander 1998), which included $53 \%$ of the wetlands in this study, $56 \%$ of wetlands with nests, $45 \%$ of wetlands with nests on paved roads, and $65 \%$ of wetlands with nests along gravel roads.
The model-averaged estimate of nest survival in this study $(0.278$, SE 0.048) was comparable to other studies of Ring-necked Ducks conducted in more human-impacted landscapes. Previous studies in Minnesota reported nest survival rates of 0.44 (range 0.17 0.88 ) in the forest (Roy et al. 2012) and 0.341 (90\% CI: 0.208 0.572 ) in the forest-prairie transition (Maxson and Riggs 1996). Nest success in Maine (apparent nest success, 0.38 [range 0.320.42], McAuley and Longcore 1989) and Manitoba (0.32 SE 0.11; 95\% CI 0.11-0.52; Koons and Rotella 2003) was also comparable, indicating some consistency over time and geographically, although anthropogenic influences elsewhere were not examined in any of these studies. Compared to these other studies, nest survival near gravel roads was low. I did consider the possibility that attaching transmitters might reduce nest survival but this was not supported by the data. Right-censoring all nests after transmitter attachment produced similar nest survival estimates (0.315, SE 0.058) and conclusions were similar. 
Gravel roads in this study were more common in forested areas that were less developed, and many important nest predators, like red foxes, are found at higher densities in more intact (rural) forested areas (Randa and Yunger 2006). Yet other predators benefit from fragmentation and edge effects (Chalfoun et al. 2002) and do quite well in human-impacted landscapes (Randa and Yunger 2006). Thus road effects on nest survival are likely to vary among predator communities and landscape types. Road effects on predators might also vary with changes in the predator community or with annual changes in availability of other food sources (Pescador and Peris 2007).

Predation was the most common cause of nest failure in this study and was $11 \%$ higher near gravel roads than near paved roads. A review of boreal nesting ducks by Holopainen et al. (2015) reported that nest site use and success was primarily related to predator avoidance. Other studies have reported that Ringnecked Ducks tend to nest close to the water (Maxson and Riggs 1996) or over the water (Koons and Rotella 2003), but in this study, Ring-necked Ducks nested farther from open water. Perhaps nesting closer to the road and farther from open water offered more secure nest locations in this landscape, or perhaps nesting farther from open water offered shorter overland brood movements for hens that left nesting wetlands for other broodrearing areas.

Brood survival was higher in wetlands with more open water area and less nesting habitat. Hens may move broods from nesting lakes to get to better brood-rearing areas (Dzubin and Gollop 1972, Ball et al. 1975, Rotella and Ratti 1992, Wayland and McNicol 1994). Better brood-rearing areas might have more invertebrates for ducklings or provide more safety from duckling predators (Talent et al. 1982, Rotella and Ratti 1992, Wayland and McNicol 1994, Grand and Flint 1996) than nesting areas. Important duckling predators in forested portions of Minnesota include mink, Bald Eagles (Haliaeetus leucocephalus), turtles, and fish (Roy et al. 2012), yet few of the nesting and brood-rearing lakes in this study had fish. Mink prefer semipermanent and permanent wetlands with large open water areas (Sargeant and Arnold 1984, Arnold and Fritzell 1990), but similar to raccoons, travel along wetland edges (Gerell 1970, Barding and Nelson 2008) and are opportunistic. More open water provides better visibility for ducklings to detect predators and dive to escape. Lesser scaup, another boreal nesting diver, also have lower nest success near large lakes but hens with broods preferred them (Toft et al. 1982, Corcoran et al. 2007).

Brood age was an important predictor in models of brood survival. Most mortality occurred in the first 10 days and survival improved with age. This pattern of high mortality in the first weeks after hatch has been documented previously in Ringnecked Ducks in Maine (McAuley and Longcore 1988) as well as in other diving ducks such as Canvasbacks (Aythya valisineria; Korschgen et al. 1996b) and other duck species (Ball et al. 1975, Talent et al. 1983, Orthmeyer and Ball 1990, Grand and Flint 1996, Dzus and Clark 1997, Guyn and Clark 1999, Gendron and Clark 2002, Pietz et al. 2003). Older ducklings are better able to thermo-regulate and respond appropriately to danger.

Brood survival of Ring-necked Ducks in Minnesota (0.235) was similar to other diving ducks in the boreal forest (e.g., 5 of 22 and 1 of 10 scaup broods to 30 days [Greater Scaup (Aythya marila) and Lesser Scaup combined] in each of 2 years; Walker and Lindberg 2005), but was low compared to dabbling ducks (Mallards: Talent et al. 1983, Orthmeyer and Ball 1990, Stafford et al. 2002; Wood Ducks: Ball et al. 1975, Davis et al. 2007; and Gadwall [Mareca strepera]: Pietz et al. 2003), and diving ducks in parkland habitats of Minnesota and Manitoba (Canvasbacks; Korschgen et al. 1996b, Leonard et al. 1996). Brood survival in Ring-necked Ducks has only been examined previously in Maine and was substantially higher there ( $77 \%$ to 45 days, $n=64$; McAuley and Longcore 1988). Duckling survival in the same study was $37 \%$. Brood survival may have been impacted by marking hens in this study, but was not supported by the data.

\section{CONCLUSION}

This study is the first to examine wetland and anthropogenicdevelopment covariates that might influence Ring-necked Duck nest and brood survival, and contributes the first information on brood survival of Ring-necked Ducks in the Great Lakes Region. Wetland-related brood survival differences were identified, and wetlands with larger open water area and less nesting habitat were indicated as important for brood-rearing, necessitating the consideration of various life-history stages in habitat use (Nummi and Pöysä 1993, Roy et al. 2014). Habitat shifts among breeding stages of other boreal ducks have been demonstrated in European studies (Pehrsson 1984, Nummi and Pöysä 1993, Paasivaara and Pöysä 2008). Importantly, in the fall, juvenile Ring-necked Ducks require wetlands with still different attributes from wetlands used for brood-rearing (Roy et al. 2014), further illustrating the importance of considering multiple life-history stages and broader perspectives in conservation. Further consideration of community perspectives is also encouraged, including marking predators to understand movements as they relate to roads and wetland use, to help elucidate the mechanisms behind the patterns observed with roads. As anthropogenic development continues to increase in the boreal forest, understanding how impacts vary among species will help prioritize conservation actions and provide a context for decisions that cannot benefit all life-history stages and all species to the same extent.

Responses to this article can be read online at: http://www.ace-eco.org/issues/responses.php/1212

\section{Acknowledgments:}

I would like to thank the Upper Mississippi River and Great Lakes Region Joint Venture and Minnesota Department of Natural Resources for funding and support during 2008-2010 and 20112012, respectively. Numerous interns helped with data collection including P. Christensen, S. Bischof, R. Hanauer, T. Peterson, E. Zlonis, N. Besasie, M. Weegman, T. Laine, P. Flicek, J. Lambert, E. Butler, A. Fotjik, T. Brenny, S. Adams, D. Essian, and J. Gable. J. Heineman flew aerial telemetry flights to locate missing hens. E. Kaufman and E. Butler provided veterinary expertise. M. Kelly and E. Butler assisted in obtaining surgical supplies. Numerous landowners provided access to their properties to search for nests, hens, and broods. C. Herwig and J. Kennedy helped in the field, with data entry, and GIS during early years of the project. The staff of the Wetland Wildlife Populations and Research Group of the 
Minnesota Department of Natural Resources provided discussion and advice. J. Giudice improved this manuscript through providing statistical assistance and reviewing multiple drafts. M. Clark also reviewed an early version of this manuscript. This research complied with the Guidelines to the Use of Wild Birds in Research. Trapping and radio-tagging was conducted under federal permit \#05838 issued to J. Berdeen of the Minnesota Department of Natural Resources. Todd Arnold and an anonymous reviewer made recommendations that greatly improved this manuscript.

\section{LITERATURE CITED}

Akaike, H. 1973. Information theory as an extension of the maximum likelihood principle. Pages 267-281 in B. N. Petrov, and F. Csaki, editors. Second international symposium on information theory. Akademiai Kiado, Budapest, Hungary.

Amrhein, C., J. E. Strong, and P. A. Mosher. 1992. Effect of deicing salts on metal and organic matter mobilization in roadside soils. Environmental Science and Technology 26:703-709. http:// dx.doi.org/10.1021/es00028a006

Arnold, T. W. 2010. Uninformative parameters and model selection using Akaike's Information Criterion. Journal of Wildlife Management 74(6):1175-1178. http://dx.doi.org/10.1111/ j.1937-2817.2010.tb01236.x

Arnold, T. W., and E. K. Fritzell. 1990. Habitat use by male mink in relation to wetland characteristics and avian prey abundances. Canadian Journal of Zoology 68:2205-2208. http://dx.doi. org/10.1139/z90-306

Ball, I. J., D. S. Gilmer, L. M. Cowardin, and J. H. Reichman. 1975. Survival of Wood Duck and Mallard broods in northcentral Minnesota. Journal of Wildlife Management 39 (4):776-780. http://dx.doi.org/10.2307/3800241

Barding, E. E., and T. A. Nelson. 2008. Raccoons use habitat edges in northern Illinois. American Midland Naturalist 159:394-402. http://dx.doi.org/10.1674/0003-0031(2008)159[394: RUHEIN]2.0.CO;2

Barthelmess, E. L., and M. S. Brooks. 2010. The influence of body-size and diet on road-kill trends in mammals. Biodiversity and Conservation 19:1611-1629. http://dx.doi.org/10.1007/ s10531-010-9791-3

Benítez-López, A., R. Alkemade, and P. A. Verweij. 2010. The impacts of roads and other infrastructure on mammal and bird populations: a meta-analysis. Biological Conservation 143:1307-1316. http://dx.doi.org/10.1016/j.biocon.2010.02.009

Brandt, J. P. 2009. The extent of the North American boreal zone. Environmental Reviews 17:101-161. http://dx.doi.org/10.1139/ A09-004

Burnham, K. P., and D. R. Anderson. 2002. Model selection and multimodel inference: a practical information-theoretic approach. Second edition, Springer, New York, New York, USA. http://dx. doi.org/10.1007/b97636

Chalfoun, A. D., F. R. Thompson III, and M. J. Ratnaswamy. 2002. Nest predators and fragmentation: a review and metaanalysis. Conservation Biology 16:306-318. http://dx.doi. org/10.1046/j.1523- 1739.2002.00308.x
Cooch, E. G., and G. C. White. 2014. Program Mark: a gentle introduction. Thirteenth edition. [online] URL: http://www. phidot.org/software/mark/docs/book/

Corcoran, R. M., J. R. Lovvorn, M. R. Bertram, and M. T. Vivion. 2007. Lesser Scaup nest success and duckling survival on the Yukon flats, Alaska. Journal of Wildlife Management 71 (1):127-134. http://dx.doi.org/10.2193/2005-534

Cowardin, L. M., D. S. Gilmer, and C. W. Schaiffer. 1985. Mallard recruitment in the agricultural environment of North Dakota. Wildlife Monographs 92:3-37.

Dale, V. H., L. A. Joyce, S. McNulty, R. P. Neilson, M. P. Ayres, M. D. Flannigan, P. J. Hanson, L. C. Irland, A. E. Lugo, C. J. Peterson, D. Simberloff, F. J. Swanson, B. J. Stocks, and B. M. Wotton. 2001. Climate change and forest disturbances. Bioscience 51(9):723-734. http://dx.doi.org/10.1641/0006- 3568(2001)051 [0723:CCAFD]2.0.CO;2

Davis, J. B., R. R. Cox, Jr., R. M. Kaminski, and B. D. Leopold. 2007. Survival of Wood Duck ducklings and broods in Mississippi and Alabama. Journal of Wildlife Management 71(2):505-517. http://dx.doi.org/10.2193/2005-720

DesGranges, J. L, and M. Darveau. 1985. Effect of lake acidity and morphometry on the distribution of aquatic birds in southern Quebec. Ecography 8:181-190. http://dx.doi.org/10.1111/j.16000587.1985.tb01169.x

Devries, J. H., R. W. Brook, D. W. Howerter, and M. G. Anderson. 2008. Effects of spring body condition and age on reproduction in Mallards (Anas platyrhynchos). Auk 125:618-628. http://dx.doi. org/10.1525/auk.2008.07055

Dinsmore, S. J., and J. J. Dinsmore. 2007. Modeling avian nest survival in program MARK. Studies in Avian Biology 34:73-83.

Dinsmore, S. J., G. C. White, and F. L. Knopf. 2002. Advanced techniques for modeling avian nest survival. Ecology 83:3476-3488. http://dx.doi.org/10.1890/0012- 9658(2002)083 [3476:ATFMAN]2.0.CO;2

Drever, M. C., R. G. Clark, C. Derksen, S. M. Slattery, P. Toose, and T. D. Nudds. 2012. Population vulnerability to climate change linked to timing of breeding in boreal ducks. Global Change Biology 18:480-492. http://dx.doi.org/10.1111/j.1365-2486.2011.02541. $\mathrm{x}$

Dzubin, A., and J. B. Gollop. 1972. Aspects of Mallard breeding ecology in Canadian parkland and grassland. U.S. Fish and Wildlife Service Research Report 2:113-152.

Dzus, E. H., and R. G. Clark. 1997. Overland travel, food abundance, and wetland use by Mallards: relationships with offspring survival. Wilson Bulletin 109:504-515.

Emery, R. B., D. W. Howerter, L. M. Armstrong, M. G. Anderson, J. H. Devries, and B. L. Joynt. 2005. Seasonal variation in waterfowl nesting success and its relation to cover management in the Canadian prairies. Journal of Wildlife Management 69:1181-1193. http://dx.doi.org/10.2193/0022- 541X(2005)069 [1181:SVIWNS]2.0.CO;2

Fahrig, L., and T. Rytwinski. 2009. Effects of roads on animal abundance: an empirical review and synthesis. Ecology and Society 14(1):21. http://dx.doi.org/10.5751/ES-02815-140121 
Fast, P. L. F., R. G. Clark, R. W. Brook, and J. E. Hines. 2004. Patterns of wetland use by brood-rearing Lesser Scaup in the northern boreal forest of Canada. Waterbirds 27:177-182. http:// dx.doi.org/10.1675/1524-4695(2004)027[0177:POWUBB]2.0.CO;2

Forman, R. T. T., and L. E. Alexander. 1998. Roads and their major ecological effects. Annual Review of Ecology and Systematics 29:207-231. http://dx.doi.org/10.1146/annurev. ecolsys.29.1.207

Forman, R. T. T., D. S. Friedman, D. Fitzhenry, J. D. Martin, A. S. Chen, and L. E. Alexander. 1997. Ecological effects of roads: toward three summary indices and an overview for North America. Pages 40-54 in K. Canters, editor. Habitat fragmentation \& infrastructure. Ministry of Transportation, Public Works \& Water Management, Delft, The Netherlands.

Francis, C. D., and J. R. Barber. 2013. A framework for understanding noise impacts on wildlife: an urgent conservation priority. Frontiers in Ecology and the Environment 11:305-313. http://dx.doi.org/10.1890/120183

Francis, C. D., C. P. Ortega, and A. Cruz. 2009. Noise pollution changes avian communities and species interactions. Current Biology 19:1415- 1419. http://dx.doi.org/10.1016/j.cub.2009.06.052

Gendron, M., and R. G. Clark. 2002. Survival of Gadwall and Mallard ducklings in southcentral Saskatchewan. Journal of Wildife Management 66:170-180. http://dx.doi.org/10.2307/3802883

Gerell, R. 1970. Home ranges and movements of the mink Mustela vison Schreber in southern Sweden. Oikos 21:160-173. http://dx.doi.org/10.2307/3543672

Gollop, J. B., and W. H. Marshall. 1954. A guide to aging duck broods in the field. Mississippi Flyway Council Technical Section Report.

Grand, J. B., and P. L. Flint. 1996. Survival of Northern Pintail ducklings on the Yukon-Kuskokwim Delta, Alaska. Condor 98:48-53. http://dx.doi.org/10.2307/1369507

Granfors, D. A., and L. D. Flake. 1999. Wood Duck brood movements and habitat use on prairie rivers in South Dakota. Journal of Wildlife Management 63:639-649. http://dx.doi. org/10.2307/3802653

Grant, T. A., and T. L. Shaffer. 2012. Time-specific patterns of nest survival for ducks and passerines breeding in North Dakota. Auk 129:319-328. http://dx.doi.org/10.1525/auk.2012.11064

Guyn, K. L., and R. G. Clark. 1999. Factors affecting survival of Northern Pintail ducklings in Alberta. Condor 101:369-377. http://dx.doi.org/10.2307/1370000

Havera, S. P., L. R. Boens, M. M. Georgi, and R. T. Shealy. 1992. Human disturbance of waterfowl on Keokuk Pool, Mississippi River. Wildlife Society Bulletin 20:290-298.

Hepp, G. R., and R. A. Kennamer. 1993. Effects of age and experience on reproductive performance of Wood Ducks. Ecology 74:2027-2036. http://dx.doi.org/10.2307/1940848

Hilli-Lukkarinen, M. M. Kuitunen, and J. Suhonen. 2011. The effect of changes in land use on waterfowl species turnover in Finnish boreal lakes. Ornis Fennica 88:185-194.
Hohman, W. L. 1986. Changes in body weight and composition of breeding Ring-necked Ducks (Aythya collaris). Auk 103:181188.

Holopainen, S., C. Arzel, L. Dessborn, J. Elmberg, G. Gunnarsson, P. Nummi, H. Pöysä, and K. Sjöberg. 2015. Habitat use in ducks breeding in boreal freshwater wetlands: a review. European Journal of Wildlife Research 61:339-363. http://dx.doi. org/10.1007/s10344-015-0921-9

Hunt, E. G., and W. Anderson. 1966. Renesting of ducks at Mountain Meadows, Lassen County, California. California Fish and Game Journal 52:17-27.

Intergovernmental Panel on Climate Change (IPCC). 2001. Climate change 2001: the scientific basis. Contribution of Working Group I to the Third Assessment Report of the Intergovernmental Panel on Climate Change. Cambridge University Press, New York, New York, USA.

Iverson, L. R., and A. M. Prasad. 2001. Potential changes in tree species richness and forest community types following climate change. Ecosystems 4:186-199. http://dx.doi.org/10.1007/s10021-0010003-6

Jackson, C. H. 2011. Multi-state models for panel data: the msm package for R. Journal of Statistical Software 38:1-29. http://dx. doi.org/10.18637/jss.v038.i08

Jaeger, J. A. G., J. Bowman, J. Brennan, L. Fahrig, D. Bert, J. Bouchard, N. Charbonneau, K. Frank, B. Gruber, and K. T. von Toschanowitz. 2005. Predicting when animal populations are at risk from roads: an interactive model of road avoidance behavior. Ecological Modelling 185:329-348. http://dx.doi.org/10.1016/j. ecolmodel.2004.12.015

Jahren, C. T., D. Smith, J. Thorius, M. Rukashaza-Mukome, D. White, and G. Johnson. 2005. Economics of upgrading an aggregate road. Minnesota Department of Transportation, St. Paul, Minnesota, USA. [online] URL: http://www.lrrb.org/ media/reports/200509.pdf

Klett, A. T., and D. H. Johnson. 1982. Variability in nest survival rates and implications to nesting studies. Auk 99:77-87. http://dx. doi.org/10.2307/4086023

Knapton, R. W., S. A. Petrie, and G. Herring. 2000. Human disturbance of diving ducks on Long Point Bay, Lake Erie. Wildlife Society Bulletin 28 (4):923-930.

Koons, D. N., and J. J. Rotella. 2003. Comparative nesting success of sympatric Lesser Scaup and Ring-necked Ducks. Journal of Field Ornithology 74:222-229. http://dx.doi.org/10.1648/0273-8570-74.3.222

Korschgen, C. E., L. S. George, and W. L. Green. 1985. Disturbance of diving ducks by boaters on a migrational staging area. Wildlife Society Bulletin 13:290-296.

Korschgen, C. E., K. P. Kenow, W. L. Green, D. H. Johnson, M. D. Samuel, and L. Sileo. 1996b. Survival of radiomarked Canvasback ducklings in northwestern Minnesota. Journal of Wildlife Management 60:120-132. http://dx.doi.org/10.2307/3802046

Korschgen, C. E., K. P. Kenow, W. L. Green, M. D. Samuel, and L. Sileo. 1996a. Technique for implanting radiotransmitters 
subcutaneously in day-old ducklings. Journal of Field Ornithology 67:392-397.

Kroening, S., and M. Ferrey. 2013. The condition of Minnesota's groundwater, 2007-2011. Minnesota Pollution Control Agency, St. Paul, Minnesota, USA. http://www.pca.state.mn.us/sites/ default/files/wq-am1-06.pdf

Lawrence, J. S., and J. H. Giudice. 2013. 2013 Ring-necked Duck breeding pair survey. Pages 141-157 in Status of wildlife populations 2013. Minnesota Department of Natural Resources, St. Paul, Minnesota, USA.

Leipus, L., D. Butkus, and T. Janusevicius. 2010. Research on motor transport produced noise on gravel and asphalt roads. Baltic Journal of Road and Bridge Engineering 5:125-131. http:// dx.doi.org/10.3846/bjrbe.2010.18

Lemelin, L.-V., M. Darveau, L. Imbeau, and D. Bordage. 2010. Wetland use and selection by breeding waterbirds in the boreal forest of Quebec, Canada. Wetlands 30:321-332. http://dx.doi. org/10.1007/s13157-010-0024 -Z

Leonard, J. P., M. G. Anderson, H. H. Prince, and R. B. Emery. 1996. Survival and movements of Canvasback ducklings. Journal of Wildlife Management 60:863-874. http://dx.doi.org/10.2307/3802387

Machin, K. L., and N. A. Caulkett. 2000. Evaluation of isoflurane and propofol anesthesia for intra-abdominal transmitter placement in nesting female Canvasback ducks. Journal of Wildlife Diseases 36:324-334. http://dx.doi.org/10.7589/0090-3558-36.2.324

Maxson, S. J., and M. R. Riggs. 1996. Habitat use and nest success of overwater nesting ducks in westcentral Minnesota. Journal of Wildlife Management 60:108-119. http://dx.doi.org/10.2307/3802045

Mazerolle, M. J. 2017. AICcmodavg: model selection and multimodel inference based on $(Q) A I C(c)$. $\mathrm{R}$ package version 2.1-1. [online] URL: https://cran.r-project.org/package=AICcmodavg

McAuley, D. G., and J. R. Longcore. 1988. Survival of juvenile Ring-necked Ducks on wetlands of different $\mathrm{pH}$. Journal of Wildlife Management 52:169-176. http://dx.doi.org/10.2307/3801219

McAuley, D. G., and J. R. Longcore. 1989. Nesting phenology and success of Ring-necked Ducks in east-central Maine. Journal of Field Ornithology 60:112-119.

McGurk, B. J., and D. R. Fong. 1995. Equivalent roaded area as a measure of cumulative effect of logging. Environmental Management 19:609- 621. http://dx.doi.org/10.1007/BF02471972

Mendall, H. L. 1958. Ring-necked Duck in the Northeast. University of Maine, Orono, Maine, USA.

Minnesota Department of Natural Resources (MNDNR). 2006. $A$ vision for wildlife and its use - goals and outcomes 2006-2012. Minnesota Department of Natural Resources, St. Paul, Minnesota, USA. [online] URL: http://files.dnr.state.mn.us/ aboutdnr/reports/strategic-documents/wildlife-stategic-plan05-12. $\underline{\mathrm{pdf}}$

Montgomery, J. 1985. A collar radio-transmitter attachment for Wood Ducks and other avian species. Proceedings of the International Conference on Wildlife Biotelemetry 5:19-27.
Morgan, E., W. Porak, and J. Arway. 1983. Controlling acidictoxic metal leachates from southern Appalachian construction slopes: mitigating stream damage. Transportation Research Record 948:10-16.

Murdy, H. W. 1965. Population dynamics and breeding biology of waterfowl on the Yellowknife study area, Northwest Territories; progress report, 1964. U.S. Fish and Wildlife Service, Bureau of Sport Fish and Wildlife, Northern Prairie Wildlife Research Center, Jamestown, North Dakota, USA.

Nummi, P., and H. Pöysä. 1993. Habitat associations of ducks during different phases of the breeding season. Ecography 16:319328. http://dx.doi.org/10.1111/j.1600-0587.1993.tb00221.x

Orthmeyer, D. L., and I. J. Ball. 1990. Survival of Mallard broods on Benton Lake National Wildlife Refuge in northcentral Montana. Journal of Wildlife Management 54:62-66. http://dx. doi.org/10.2307/3808901

Paasivaara, A., and H. Pöysä. 2008. Habitat-patch occupancy in the Common Goldeneye (Bucephala clangula) at different stages of the breeding cycle: implications to ecological processes in patchy environments. Canadian Journal of Zoology 86:744-755. http://dx.doi.org/10.1139/Z08-051

Parris, K. M., and A. Schneider. 2008. Impacts of traffic noise and traffic volume on birds of roadside habitats. Ecology and Society 14(1):29. http://dx.doi.org/10.5751/ES-02761-140129

Paszkowski, C. A., and W. M. Tonn. 2000. Community concordance between the fish and aquatic birds of lakes in northern Alberta, Canada: the relative importance of environmental and biotic factors. Freshwater Biology 43:421-437. http://dx.doi.org/10.1046/j.1365-2427.2000.00512.x

Pescador, M., and S. Peris. 2007. Influence of roads on bird nest predation: an experimental study in the Iberian Peninsula. Landscape and Urban Planning 82:66-71 http://dx.doi. org/10.1016/j.landurbplan.2007.01.017

Pehrsson, O. 1984. Relationships of food to spatial and temporal breeding strategies of Mallards in Sweden. Journal of Wildlife Management 48:322-339. http://dx.doi.org/10.2307/3801164

Philcox, C. K., A. L. Grogan, and D. W. MacDonald. 1999. Patterns of otter Lutra lutra road mortality in Britain. Journal of Applied Ecology 36:748-761. http://dx.doi.org/10.1046/j.13652664.1999.00441.x

Pietz, P. J., G. L. Krapu, D. A. Brandt, and R. R. Cox, Jr. 2003. Factors affecting Gadwall brood and duckling survival in Prairie pothole landscapes. Journal of Wildlife Management 67:564-575. http://dx.doi.org/10.2307/3802714

R Core Team. 2017. R: A language and environment for statistical computing. R Foundation for Statistical Computing, Vienna, Austria. [online] URL: https://www.R-project.org/

Randa, L. A., and J. A. Yunger. 2006. Carnivore occurrence along an urban-rural gradient: a landscape level analysis. Journal of Mammalogy 87:1154-1164. http://dx.doi.org/10.1644/05-MAMMA-224R 2.1

Reijnen, R., R. Foppen, and H. Meeuwsen. 1996. The effects of 
Avian Conservation and Ecology 13(1): 20

traffic on the density of breeding birds in Dutch agricultural grasslands. Biological Conservation 75:255-260. http://dx.doi. org/10.1016/0006- 3207(95)00074-7

Rempel, R. S., K. F. Abraham, T. R. Gadawski, S. Gabor, and R. K. Ross. 1997. A simple wetland habitat classification for boreal forest waterfowl. Journal of Wildlife Management 61:746-757. http://dx.doi.org/10.2307/3802181

Ringelman, J. K., and J. R. Longcore. 1982. Survival of juvenile Black Ducks during brood rearing. Journal of Wildlife Management 46:622-628. http://dx.doi.org/10.2307/3808552

Rotella, J. 2006. Nest survival. Chapter 17 in E. Cooch and G. White, editors. Program MARK-“A gentle introduction.”[online] URL: http://www.phidot.org/software/mark/docs/book/

Rotella, J. J., and J. T. Ratti. 1990. Use of methoxyflurane to reduce nest abandonment in Mallards. Journal of Wildlife Management 54:627-628. http://dx.doi.org/10.2307/3809360

Rotella, J. J., and J. T. Ratti. 1992. Mallard brood survival and wetland habitat conditions in southwestern Manitoba. Journal of Wildlife Management 56:499-507. http://dx.doi.org/10.2307/3808865

Roy, C. L., J. Fieberg, C. Scharenbroich, and C. M. Herwig. 2014. Thinking like a duck: fall lake use and movement patterns of juvenile Ring-necked Ducks before migration. PLOS ONE 9(2): e88597. http://dx.doi.org/10.1371/journal.pone.0088597

Roy, C. L., C. M. Herwig, W. L. Hohman, and R. T. Eberhardt. 2012. The Ring-necked Duck (Aythya collaris). In A. Poole, editor. The birds of North America online. Cornell Lab of Ornithology, Ithaca, New York, USA. https://doi.org/10.2173/bna.329

Saporta, R., J. R. Malcolm, and D. L. Martell. 1998. The impact of climate change on Canadian forests. Pages 319-382 in G. Koshida and W. Avis, editors. The Canada Country study: climate impacts and adaptation. National sectoral volume. Environment Canada, Toronto, Ontario, Canada.

Sargeant, A. B., and P. M. Arnold. 1984. Predator management for ducks on waterfowl production areas in the Northern Plains. Proceedings of the Vertebrate Pest Conference 11:161-167.

Sarvis, J. E. 1972. The breeding biology and ecology of Ring-necked Ducks in northern Michigan. Thesis, Utah State University, Logan, Utah, USA.

Seber, G. A. F. 1982. The estimation of animal abundance and related parameters. Second edition. Macmillan, New York, New York, USA.

Siegel, L. 2007. Hazard identification for human and ecological effects of sodium chloride road salt. New Hampshire Department of Environmental Services Water Division, Concord, New Hampshire, USA. [online] URL: http://www.rebuildingi93.com/ documents/environmental/Chloride-TMDL-Toxicological-Evaluation. pdf

Slattery, S. M., J. L. Morissette, G. C. Mack, and E. W. Butterworth. 2011. Waterfowl conservation planning: science needs and approaches. Pages 23-40 in J. V. Wells, editor. Boreal birds of North America: a hemispheric view of their conservation links and significance. Studies in Avian Biology (no. 41) University of California Press, Berkeley, California, USA.

Sorenson, M. D. 1989. Effects of neck collars on female Redheads.
Journal of Field Ornithology 60(4):523-528.

Stafford, J. D., L. D. Flake, and P. W. Mammenga. 2002. Survival of Mallard broods and ducklings departing overwater nesting structures in eastern South Dakota. Wildlife Society Bulletin 30:327-336.

Stephens, S. E., J. J. Rotella, M. S. Lindberg, M. L. Taper, and J. K. Ringleman. 2005. Duck nest survival in the Missouri Coteau of North Dakota: landscape effects at multiple spatial scales. Ecological Applications 15:2137-2149. http://dx.doi.org/10.1890/04-1162

Sugiura, N. 1978. Further analysis of the data by Akaike's Information Criterion and the finite corrections. Communications in Statistics, Theory and Methods 7:13-26. http://dx.doi. org/10.1080/03610927808827599

Talent, L. G., R. L. Jarvis, and G. L. Krapu. 1983. Survival of Mallard broods in south-central North Dakota. Condor 85:74-78. http://dx.doi.org/10.2307/1367893

Talent, L. G., G. L. Krapu, and R. L. Jarvis. 1982. Habitat use by Mallard broods in south-central South Dakota. Journal of Wildlife Management 46:629-635. http://dx.doi.org/10.2307/3808553

Toft, C. A., D. L. Trauger, and H. W. Murdy. 1982. Tests for species interactions: breeding phenology and habitat use in subarctic ducks. American Naturalist 120:586-613. http://dx.doi.org/10.1086/284015

Townsend, G. H. 1966. A study of waterfowl nesting on the Saskatchewan River Delta. Canadian Field-Naturalist 80:74-88.

Traylor, J. T., and R. T. Alisauskas. 2006. Effects of intrinsic and extrinsic factors on survival of White-winged Scoter (Melanitta fusca deglandi) ducklings. Auk 123:67-81. http://dx.doi. org/10.1642/0004-8038(2006)123[0067:EOIAEF]2.0.CO;2

Trombulak, S. C., and C. A. Frissell. 2000. Review of ecological effects of roads on terrestrial and aquatic communities. Conservation Biology 14:18-30. http://dx.doi.org/10.1046/ j.1523-1739.2000.99084.X

United States Fish and Wildlife Service. 2002. Waterfowl population status, 2002. U. S. Department of the Interior, Washington, D.C., USA.

Venables, W. N., and B. D. Ripley. 2002. Modern applied statistics with $S$. Fourth Edition. Springer, New York, New York, USA. http://dx.doi.org/10.1007/978-0-387-21706-2

Walker, J., and M. S. Lindberg. 2005. Survival of scaup ducklings in the boreal forest of Alaska. Journal of Wildlife Management 69:592-600. http://dx.doi.org/10.2193/0022- 541X(2005)069[0592: SOSDIT]2.0.CO;2

Walker, J., M. S. Lindberg, M. C. MacCluskie, M. J. Petrula, and J. S. Sedinger. 2005. Nest survival of scaup and other ducks in the boreal forest of Alaska. Journal of Wildlife Management 69:582-591. http://dx.doi.org/10.2193/0022-541X(2005)069[0582: NSOSAO]2.0.CO;2

Wayland, M., and D. K. McNicol. 1994. Movements and survival of Common Goldeneye broods near Sudbury, Ontario, Canada. Canadian Journal of Zoology 72:1252-1259. http://dx.doi. org/10.1139/z94-167 
Weller, M. W. 1956. A simple field candler for waterfowl eggs. Journal of Wildlife Management 20:111-113. http://dx.doi. org/10.2307/3797414

Weller, M. W. 1957. An automatic nest-trap for waterfowl. Journal of Wildlife Management 21:456-458. http://dx.doi.org/10.2307/3796681

White, G. C., and K. P. Burnham. 1999. Program MARK: survival estimation for populations of marked animals. Bird Study 46 (Supplement):120 -138. http://dx.doi.org/10.1080/00063659909477239

Wilcox, D. A. 1986. The effects of deicing salts on vegetation in Pinhook Bog, Indiana. Canadian Journal of Botany 64:865-874. http://dx.doi.org/10.1139/b86-113

Wolff, P. J., C. A. Taylor, E. J. Heske, and R. L. Schooley. 2015. Habitat selection by American mink during summer is related to hotspots of crayfish availability. Wildlife Biology 21:9-17. http:// dx.doi.org/10.2981/wlb.00031

Zicus, M. C., R. T. Eberhardt, J. DiMatteo, and L. L. Johnson. 2004. Bemidji area Ring-necked Duck survey. Pages 169-183 in M. W. DonCarlos, R. O. Kimmel, J. S. Lawrence, and M. S. Lenarz, editors. Summaries of wildlife research findings 2003. Minnesota Department of Natural Resources, St. Paul, Minnesota, USA.

Zicus, M. C., D. P. Rave, J. R. Fieberg, and J. H. Giudice. 2008. Distribution and abundance of Minnesota breeding Ring-necked Ducks, Aythya collaris. Wildfowl 58:31-45. 